\title{
Climatic change in Central Asia during MIS 3/2: a case study using biological responses from Lake Baikal
}

George E.A. Swann ${ }^{1 *}$, Anson W. Mackay ${ }^{1}$, Melanie J. Leng ${ }^{2}$, Francois Demory ${ }^{3}$

${ }^{1}$ Environmental Change Research Centre, Department of Geography, University College London, 26 Bedford Way, London, WC1H OAP, UK

${ }^{2} N E R C$ Isotope Geosciences Laboratory, British Geological Survey, Keyworth, Nottingham, NG12 5GG, UK

${ }^{3}$ GeoForschungsZentrum Potsdam, Sedimentation and Basin Analysis, Telegrafenberg, D-14473 Potsdam,

Brandenburg, Germany

*g.swann@ucl.ac.uk

\begin{abstract}
A Marine Isotope Stage (MIS) 3/early MIS 2 section from a structural high along the east coast of the North Basin of Lake Baikal was analysed for diatoms, $\mathrm{C} / \mathrm{N}$ ratios and organic carbon isotope ratios. Diatoms were present throughout MIS 3 and early MIS 2, with high concentrations of the planktonic taxa C. sp. c.f. gracilis between 54 kyr BP and 51.5 kyr BP indicating relatively warm, interstadial, conditions. Following a \%TOC inferred climatic cooling between $43.2 \mathrm{kyr} \mathrm{BP}$ and $39.1 \mathrm{kyr}$, evidence of a more muted $\delta^{13} \mathrm{C}_{\text {(organic) }}$ and \% $\mathrm{TOC}$ inferred climatic warming from c.39.1-c.34.7 kyr BP coincides with a period of very high diatom concentrations, indicating high aquatic productivity, at the Buguldeika Saddle in the South Basin of Lake Baikal. No evidence exists for a 'Kuzmin' catchment erosional event in the North Basin during MIS 3. This may however reflect the location of the coring site away from major riverine inputs. Abrupt climatic cooling at the culmination of both warm phases in the North Basin are associated, on the basis of the palaeomagnetic age-model and correlations to existing sites in Lake Baikal, with the initiation of Heinrich events 5 (c.50 kyr BP) and 4 (c.35 kyr BP) respectively in the North Atlantic. The amount of organic material declines across the MIS 3/MIS 2 transition while constant $\mathrm{C} / \mathrm{N}$ ratios suggest organic material to be predominantly derived from phytoplankton. An increase in $\delta^{13} \mathrm{C}_{\text {(organic) }}$ at the MIS 3/MIS 2 transition may therefore indicate changes in aquatic productivity, $p \mathrm{CO}_{2}$ or the inorganic carbon pool.
\end{abstract}

Keywords: diatoms, organic carbon isotopes ratios, $\mathrm{C} / \mathrm{N}$ ratios, palaeolimnology, MIS 3, MIS 2

\section{Introduction}

The last glacial period in Central Asia, the Zyryanka Glacial, is separated into two cold stages, the Ermakovo and Sartan glaciation, corresponding to Marine Isotope Stages (MIS) 4 and MIS 2 respectively, and an intermediate warm period, the Karginskiy Interstadial correlating to MIS 3 (Velichko, 1984). Initially defined from deep ocean cores (Emiliani, 1955; Shackleton and Opdyke, 1973), MIS 3 represents a unique 
period in the Quaternary with the presence of warm, interstadial, conditions in which Homo sapiens migrated into Europe and Neanderthals became extinct (van Andel, 2002; D'Errico and Goni, 2003). Lasting from c.59 to c. 29 calendar (cal) kyr BP (c.56 to $25{ }^{14} \mathrm{C}$ kyr BP) (Voelker et al. 1998, van Kreveld et al. 2000), MIS 3 is marked by large-scale deglaciation in Europe and Central Asia, intermixed by Heinrich and Dansgaard/Oeschger (D/O) events in the North Atlantic region and the development of large alluvial plains in south west Siberia (Nemchinov et al. 1999; Arnold et al. 2002).

Numerous attempts have been made to establish the global extent and impact of Heinrich and D/O events in both terrestrial and oceanic records, despite uncertainty over their initiation and mechanism (Broecker, 1998, 2003; Cane, 1998; Stocker, 1998; Peterson et al. 2000; Maslin et al. 2001; Elliot et al. 2002; Hendy et al. 2002). MIS 3, containing Heinrich events 5 to 3 and D-O events 17-4, remains though a relatively unknown period when compared to the Last Interglacial (MIS 5e), the Last Glacial-Interglacial Transition (LGIT) and the Holocene, with less than 200 studies containing the 500 years or better temporal resolution needed to detect millennial scale climatic events (Voelker et al.. 2002). Uncertainty also prevails over regional, long-term climatic trends during the interstadial with many studies focused on North Atlantic marine cores (e.g. Elliot et al.. 1998) or European terrestrial sequences (e.g. Thouveny et al. 1994; Allen et al. 1999, Huntley et al. 2003). At present only 14 palaeoenvironmental and palaeoclimatic studies in Central Asia contain a sufficiently high resolution to detect Heinrich events and so provide a detailed insight into the long term climatic trends during MIS 3 (Voelker et al. 2002). Of these, the majority concentrate on the Chinese Loess Plateau where clear evidence exists for climatic cooling during Heinrich events and D/O stadials throughout the last glacial (e.g. Porter and An, 1995).

An alternative and potentially important site for reconstructing Central Asian palaeoclimates is Lake Baikal, located in south east Siberia. Stretching from $103^{\circ} 43^{\prime}-109^{\circ} 58^{\prime}$ E to $51^{\circ} 28^{\prime}-55^{\circ} 47^{\prime} \mathrm{N}$, Lake Baikal is the world's oldest and most voluminous lake containing c. $20 \%$ of the world's surface freshwater, c. $23,000 \mathrm{~km}^{3}$. A major feature of the Lake Baikal ecosystem is the level of biological endemicity; over 2,500 species have been identified in the lake, the majority of which are endemic (Kozhova and Izmest'eva, 1998). The bottom sediments of Lake Baikal have never being glaciated, resulting in a potentially uninterrupted sedimentary record dating back to the Late/Middle Miocene (Williams et al. 2001) or Middle Eocene (Hutchinson et al. 1992). This, combined with its remoteness from oceanic influence and position at the boundaries of regional weather systems, makes the lake a prime location to assess the strength of Central Asian-European climatic teleconnections (Livingstone, 1999; Horiuchi et al. 2000; Todd and Mackay, 2003).

Previous studies from Lake Baikal have reconstructed Central Asian palaeoclimates using a range of biological proxies in the sediment including biogenic silica and diatoms. Recent work at the Buguldeika Saddle in the Selenga Delta, towards the south of Lake Baikal (Fig. 1), has shown abrupt fluctuations in organic carbon isotopes and diatom abundance counts throughout MIS 3 which appear to correlate to 
Heinrich events in the North Atlantic (Prokopenko et al. 2001a,b). These episodic fluctuations during Heinrich events have been attributed to large-scale soil erosion events or "Kuzmin events" in the catchment caused by changes in the precipitation regime over the Mongolian and Buryatya steppes during the initiation of North Atlantic Heinrich events (Prokopenko et al. 2001a, b). These Kuzmin events have not been identified at other sites in Lake Baikal, such as the Academician Ridge to the north of the lake, suggesting that their presence may be restricted to changes in the composition of the suspended load of the Selenga River, opposite the Buguldeika Saddle (Prokopenko et al. 2001a). Here we have analysed the biological record from a region in the North Basin of Lake Baikal, again removed from major fluvial inputs, to provide a detailed fossil diatom assemblage record for the MIS 3 interstadial which, in conjunction with organic carbon isotopes, $\mathrm{C} / \mathrm{N}$ ratios and \% $\% \mathrm{TOC}$, enables an insight into the nature and stability of the Central Asian climate during MIS 3 in and around the Lake Baikal region.

\section{Methodology}

A 3.9 m core (CON01-603-5) was collected by a Kasten box corer in July 2001 from an elevated ridge along the eastern side of the North basin of Lake Baikal (Latitude: 53\%95'46"N Longitude: 108 91 '37"W) (Fig. 1) a site of continuous sedimentation connected, but morphologically isolated, from the Academician Ridge (see Charlet et al. this volume). For the purpose of this study, this site is henceforth referred to as Continent Ridge (Fig. 1). Age models for a pilot (CON01-603-2A) and piston core (CON01-603-2) at Continent Ridge were created by correlating material to the Ocean Drilling Program 984 core (Channell, 1999) using measurements of relative palaeointensity (Demory et al. this volume). This palaeomagnetic age model was applied to the Kasten core (CON01-603-5) analysed in this study using low field magnetic susceptibility correlations to create a MIS 4 to MIS 1 chronology with linear interpolation between tie-points and earlier (Holocene to late glacial) material dated by ${ }^{14} \mathrm{C}$ (Piotrovska et al. in press) (Fig. 2; Table 1).

Samples at $2 \mathrm{~cm}$ intervals for organic carbon isotopes and $\mathrm{C} / \mathrm{N}$ ratios were left overnight in $5 \% \mathrm{HCl}$ to remove carbonates before being filtered and washed with de-ionised water, dried and ground to a fine powder. Carbon isotopes in addition to percentage carbon and percentage nitrogen of bulk organic matter were analysed during combustion in a Carlo Erba 1500 on-line to a VG TripleTrap and Optima dual-inlet mass spectrometer. $\delta^{13} \mathrm{C}$ values were converted to the VPDB scale using a within-run laboratory standard calibrated against NBS-19 and NBS-22 with C/N ratios calibrated against an Acetanilide standard. Replicate analysis of sample material indicated a precision of $\pm 0.1 \%$ for carbon isotope measurements and \pm 0.1 for $\mathrm{C} / \mathrm{N}$ ratios.

Diatom slides were prepared using a protocol that omits any chemical treatments or centrifugation in order to minimise further diatom dissolution and valve breakage (see Mackay et al. 1998 for full details). Divinylbenzene microspheres were added to enable diatom concentrations to be calculated (Battarbee and Kneen, 1982). Diatom slides were counted using a Zeiss light microscope with oil immersion lens and phase 
contrast at x1000 magnification (Battarbee, 1986). Diatom identifications were primarily based on several Lake Baikal taxonomic papers (e.g. Foged, 1993; Nikiteeva and Likhoshway, 1994; Khursevich et al. 2001b). A full list of references used to identify Lake Baikal diatoms is detailed in Mackay et al. (2003). Diatom taxonomies were confirmed and harmonised at a diatom workshop, which included both Russian and UK Lake Baikal diatom specialists at University College London in September 2003. A minimum of 100 diatom valves (or six transects) were counted per slide with diatoms being further assigned into three dissolution stages to create a Diatom Dissolution Index (DDI) following Flower and Likhoshway (1993).

Ordination of the diatom data was conducted on all samples containing at least 100 valves using CANOCO v.4.5 (ter Braak and Šmilauer, 2002) to explore variability, dominant patterns and inter-relationships in the diatom assemblages. Detrended Correspondence Analysis (DCA) with detrending of segments, square-root transformation of species data and downweighting of rare taxa was used to determine whether diatoms exhibited a linear or unimodal response to the latent variables. DCA produced a first axis gradient length of 1.539, indicating a linear response. In subsequent Principal Components Analysis (PCA), scaling was focused on inter species correlations and scores divided by standard deviation. All diatoms were square root transformed to reduce the influence of dominant taxa. The significance of each PCA axis was tested with Broken-Stick (Frontier, 1976) using a function written for MATLAB. Zonation of the diatom data was calculated using the agglomerative cluster analysis of Constrained Incremental Sum of Squares (CONISS) with a squared chord distance dissimilarity coefficient in ZONE v.1.2 (Juggins, 1992).

\section{Results}

Magnetic susceptibility correlations indicate a MIS $4 / 3$ boundary at $370 \mathrm{~cm}$ and a MIS $3 / 2$ boundary at 170 cm (Fig. 2). Using palaeomagnetic correlations to ODP site 984 (Channell 1999), periods of low palaeointensity in the pilot core, corresponding to $250 \mathrm{~cm}$ in the Kasten core, were related to the Laschamp geomagnetic excursion at c.42 kyr BP, further anchoring the MIS 3 chronology (Demory et al. this volume). Detailed analysis of the magnetic susceptibility record at Continent Ridge and its interpretation as a palaeoclimatic proxy are presented in Demory et al. (this volume). $\mathrm{C} / \mathrm{N}$ mass ratios remain constant throughout MIS 3 and into MIS 2, with values between 6.3 and 8.9, indicating no significant terrestrial input of organic matter (Fig. 3). Low \%TOC values during the interstadial increase from 0.4 to 0.7 between 57.8 kyr BP and 43.7 kyr BP with a concurrent gradual increase in $\delta^{13} \mathrm{C}_{\text {(organic) }}$ amid oscillations between $-23.2 \%$ and $-26.1 \%$ (Fig. 3). \% TOC falls to 0.4 between $40.9 \mathrm{kyr}$ BP and $39.4 \mathrm{kyr}$ BP whereas $\delta^{13} \mathrm{C}_{\text {(organic) }}$ remains high at c. $24 \%$ with a peak value of $-23.6 \%$ at $39.4 \mathrm{kyr}$ BP. The subsequent two-stage increase in \%TOC from $39 \mathrm{kyr} \mathrm{BP}$ to $37.9 \mathrm{kyr} \mathrm{BP}$ and between $37.3 \mathrm{kyr} \mathrm{BP}$ and $36.9 \mathrm{kyr} \mathrm{BP}$ is marked by a period of $\delta^{13} \mathrm{C}_{\text {(organic) }}$ lowering to c. $-26.6 \%$ o before $\delta^{13} \mathrm{C}_{\text {(organic) }}$ increases after $37.9 \mathrm{kyr} \mathrm{BP}$ to $-24.8 \%$, values comparable to those prior to the \%TOC decline at $40.9 \mathrm{kyr}$ BP. $\delta^{13} \mathrm{C}_{\text {(organic) }}$ falls to below $-26 \%$ for the remainder of MIS 3 after $35.2 \mathrm{kyr}$ BP before increasing immediately prior to the MIS $3 / 2$ transition reaching $-22.6 \%$ during early MIS 2 after which values stabilize at c. $-24 \%$. In contrast, \%TOC decreases after $34.7 \mathrm{kyr}$ BP reaching a minima 
of c. 0.3 before the MIS $3 / 2$ transition. All diatoms in the analysed section were extensively affected by dissolution with only c. $1 \%$ of valves in a "pristine" condition. Diatom concentrations were generally extremely low throughout MIS 3 and across the MIS 3/2 transition with samples containing a mixture of extant and extinct species (Fig. 4). Diatom assemblage zones, based on CONISS cluster analysis (section 2), are described below with individual species concentrations in $\mathrm{x} 10^{5}$ valves/g dry wt. and total diatom concentrations in $\mathrm{x} 10^{7}$ valves/g dry wt.

\subsection{Diatom zone 7 (57.8-54 kyr BP)}

Low diatom concentrations prevail through zone 7 with concentrations increasing marginally from $0.014 \mathrm{x}$ $10^{7}$ valves/g dry wt. to $0.056 \times 10^{7}$ valves/g dry wt. Valves of Aulacoseira baicalensis (Meyer) Simonsen, Cyclotella minuta (Skv.) Antipova and Cyclotella ornata (Skv.) Flower are present in the zone with highly dissolved Cyclotella sp. c.f. gracilis (Nikiteeva and Likhoshway), Cyclotella iris var. insueta (Khurs.) and Staurosirella pinnata (Ehrenb.) Williams \& Round present from 55.4 kyr BP.

\subsection{Diatom zone 6 (54-53.3 kyr BP)}

Zone 6 is characterised by significant increases in diatom concentrations and high numbers of planktonic diatoms with A. baicalensis and C. minuta reaching c.8-9 × $10^{5}$ valves/g dry wt. (Fig. 4). Planothidium lanceolatum (Breb.) Round \& Bukht. and S. pinnata both decrease in abundance throughout the zone with $S$. pinnata declining from $1.38 \times 10^{5}$ valves/g dry wt. to $0.34 \times 10^{5}$ valves/g dry wt. Concurrent with these changes is the appearance of Staurosira construens var. construens (Ehrenb.) and Staurosira construens var. venter (Grun.) Williams \& Round and the establishment of C. sp. c.f. gracilis which reaches $8 \%$ abundance, $2.49 \times 10^{5}$ valves/g dry wt., at $53.3 \mathrm{kyr}$ BP.

\subsection{Diatom zone $5(53.3-51.5 \mathrm{kyr}$ BP) \& zone 4 (51.5-50.2 kyr BP)}

Individual and total diatom concentrations peak in zone 5 reaching $3.026 \times 10^{7}$ valves/g dry wt. (Fig. 4). This coincides with increases in A. baicalensis to $28.16 \times 10^{5}$ valves/g dry wt. at $52.6 \mathrm{kyr}$ BP and C. sp. c.f. gracilis (Fig. 5), which comprises 53-63\% of the diatom assemblages in zone 5, to $158.52 \times 10^{5}$ valves/g dry wt. at $52.1 \mathrm{kyr}$ BP. Further increases in C. minuta and C. ornata, result in the relative percentage of planktonic taxa increasing to c. $90 \%$ by $51.5 \mathrm{kyr}$ BP. Concentrations decline markedly in diatom zone 4 to below $0.37 \times 10^{7}$ valves/g dry wt. with decreases in all diatoms, particularly in C. sp. c.f. gracilis and $C$. ornata to c. $4-5 \times 10^{5}$ valves/g dry wt.

\subsection{Diatom zone 3 (50.2-47 kyr BP), zone 2 (47-42.5 kyr BP) \& zone 1 (42.5-23.5 kyr BP)}

Throughout zones 3 and 2, the relative percent of planktonic diatoms decreases to c.50-70\%, associated with increases in S. construens var. construens, S. construens var. venter, Fragilaria heidenii (Ostr.), $P$. lanceolata and $S$. pinnata, while C. sp. c.f. gracilis and C. minuta fall to below c. $2 \times 10^{5}$ valves/g dry wt. Total diatom concentrations increase by c.3-4 x $10^{7}$ valves/g dry wt. from concentrations in zone 4 but 
decline after $48.9 \mathrm{kyr}$ BP to $1-3 \times 10^{7}$ valves/g dry wt. from where concentrations remain unchanged until zone 1, 42.5 kyr BP. Small numbers of Crateriportula inconspicua (Mak. and Pom.) Flower and Håkansson, and the extinct taxa Cyclotella c.f. comtaeformica var. spinata (Khurs.), Stephanodiscus flabellatus (Khurs. and Log.), Stephanodiscus formosus (Khurs. and Log.) and Stephanodiscus formosus var. minor (Khurs. and Log.) are also present throughout zones 3 and 2. Zone 1, 42.5-23 kyr BP, represents a 96\% decrease in diatom concentrations from those in zone 5 with concentrations falling to c. $0.02 \times 10^{7}$ valves $/ g$ dry wt. with few diatoms being present in the analysed samples. A small increase to c. $0.07 \times 10^{7}$ valves $/ g$ dry wt. is observed between $36.2 \mathrm{kyr}$ BP and $34.2 \mathrm{kyr}$ BP.

\subsection{Numerical analysis of diatom data}

PCA of diatom data was performed on samples between $54 \mathrm{kyr}$ BP and $42.5 \mathrm{kyr}$ BP, excluding data at 44.9 kyr BP, where few diatom valves were present (Fig. 6). Statistically significant eigenvalues of 0.316 and 0.119 were produced for the first and second PCA axes respectively (Fig. 6). C. sp. c.f. gracilis was strongly aligned to the first PCA axis together with Aulacoseira ambigua (Grun.) and Aulacoseira skvortzowii (Edlund, Stoermer \& Taylor) and negatively correlated to the grouping of A. baicalensis, $C$. inconspicua, $P$. lanceolatum and Stephanodiscus carconeiformis (Khurs. and Log.), S. flabellatus, S. formosus and S. formosus var. minor. The second PCA axis was dominated by the planktonic taxa Cyclotella baicalensis (Meyer) Skv. and C. ornata with both inversely related to the benthic/littoral taxa of $F$. heidenii and $S$. construens var. construens.

\section{Discussion}

Several studies have used diatom analysis to infer past climates in Lake Baikal over a variety of timescales including the last 1000 years (Mackay et al. this volume), the Holocene (e.g. Bradbury et al. 1994), MIS 5e (e.g. Rioual et al. this volume), over the last 200,000 years (e.g. Edlund and Stoermer, 2000) and further back in the past (e.g. Khursevich 2001a). Many of these studies focus on millennial timescales and on links between climate and diatom productivity, but while changes in diatom productivity have been linked to orbital forcing and to influences from ice sheets and the North Atlantic, causal mechanisms have yet to be determined. Possible controls on diatom production have been suggested, including surface water temperature, length of ice-free season, turbidity and nutrient cycling (Colman et al. 1995) and depth of snow cover on the frozen lake in spring (Kelley 1997; Granin et al. 2000; Mackay et al. 2003). Particularly relevant to this study are the investigations on MIS 3 sediments from Lake Baikal by Edlund and Stoermer (2000) and Prokopenko et al. (2001a, b), who use diatom abundance measurements to characterise this interstadial. While Karabanov et al. (2000) suggest that it is possible to use diatom abundances alone as a relative palaeoclimate index of warmer / colder conditions, total diatom numbers ignore detail potentially provided by changes in individual species and assemblages. This study is notable therefore, as it is the first to use changing species composition in the diatom assemblages to investigate past environmental conditions 
during MIS 3 in Lake Baikal. The assemblages described here consist of a mixture between extant (e.g. $A$. baicalensis, C. minuta, C. ornata and Staurosria sp.) and extinct taxa (e.g. C. sp. c.f. gracilis).

Similarly, the interpretation of organic carbon isotopes is primarily based on changes in aquatic palaeoproductivity (Hodell and Schelske, 1998; Brenner et al. 1999; Battarbee et al. 2001). If no change occurs in the type or source of organic matter, as indicated by $\mathrm{C} / \mathrm{N}$ ratios, a reduction in biological productivity results in lower $\%$ TOC and lower $\delta^{13} \mathrm{C}_{\text {(organic) }}$ while higher $\% \mathrm{TOC}$ and higher $\delta^{13} \mathrm{C}_{\text {(organic) }}$ suggest higher productivity (Hodell and Schelske, 1998). Consequently, changes in the biological record at Continent Ridge can be used to reconstruct palaeoenvironmental changes in and around Lake Baikal and Central Asia. However, it should be noted that while diatoms constitute a major component of the phytoplankton in Lake Baikal, total productivity in the lake is also influenced by other algae including the smaller picoplankton, which bloom in summer but do not preserve in the sedimentary record (Kozhova and Izmest'eva, 1998).

The discussion of this paper is structured as follows: section 4.1 below discusses issues of diatom dissolution and resuspension with reference to the MIS 3/2 section at Continent Ridge to place in context the validity of interpreting biological proxies in the core as an accurate record of past aquatic productivity and climatic change. Sections 4.2 to 4.7 analyse the palaeoclimatic events in the biological record at Continent Ridge during MIS 3 with comparisons to other studies from Lake Baikal and Central Asia while section 4.8 examines evidence for climatic teleconnections between Europe and Central Asia during the last glacial.

\subsection{Diatom dissolution and sediment resuspension at Continent Ridge}

Uncertainty prevails over the extent to which long-term variations in fossil diatom abundance are attributable to changes in diatom dissolution rates and taphonomic processes, especially in large oligotrophic lakes such as Lake Baikal. Significant variations exists between inter and intra species susceptibility to dissolution, particularly in Lake Baikal where up to $99 \%$ of diatoms in contemporary samples are subject to these processes (Ryves et al. 2003; Battarbee et al. this volume). In Lake Baikal, contemporary studies using phytoplankton and trap arrays suggest that diatom dissolution occurs predominantly at the sediment-water interface (Ryves et al. 2003). While the degree of pristine to non-pristine diatom preservation may vary on glacial-interglacial cycles, overall water column diatom dissolution rates should not have varied markedly between the last glacial and the Holocene (Colman et al., 1995).

The presence of endemic fossil diatoms at Continent Ridge, previously believed to be extinct prior to MIS 3 (e.g. C. sp. c.f. gracilis, S. formosus, S. formosus var. minor and S. grandis, Cyclotella c.f. comtaeformica var. spinata (Khurs.), is a surprising find of this study. Seismic surveys, visual analysis of the core, and contemporary sediment trap experiments in the North Basin show no evidence for resuspension, turbidites or other redepositional processes at Continent Ridge (Charlet et al this volume; De Batist pers. comm. 2004; Sturm pers. comm. 2004) while resuspension of sediments at depths does not appear to be a significant factor 
affecting profundal sedimentation (Ryves et al. 2003). Furthermore, any turbidites would have removed material from the crest of the Continent Ridge core site to the flanks (De Batist pers. comm. 2004). Consequently, we can be confident that sediments from Continent Ridge are an undisturbed record of past environmental change through the last glacial. It may be possible therefore that $C$. gracilis, $S$. formosus, $S$. formosus var. minor and S. grandis, previously thought to be extinct at the end of MIS 5e (Khursevich, et al. 2001a), actually prevailed through MIS 4 and 3 in much reduced numbers to become extinct during the Last Glacial Maximum (LGM). Support for this exists from the very high concentrations of $C$. gracilis found in the south of Lake Baikal at the Buguldeika Saddle during MIS 3 (Edlund and Stoermer, 2000). The C. sp. c.f. gracilis found at Continent Ridge during MIS 3 is likely to be the same as the C. gracilis at the Buguldeika Saddle (Edlund and Stoermer, 2000) though size ranges for the taxa at both sites agree more with those in Bradbury et al. (1994) than those proposed by Nikiteeva and Likhoshway (1994). Consequently, adjustments are needed to the Local Diatom Assemblages Zones (LDAZ) proposed in Khursevich, et al.. (2001a) between MIS 5e and MIS 3. More intriguing is evidence here for C. c.f. comtaeformica var. spinata. C. comtaeformica var. spinata is an endemic diatom previously only documented between $1.85 \mathrm{Ma} \mathrm{BP}$ and 1.25 Ma BP (Khursevich, et al. 2001b). Given that any sedimentary disturbances at the coring site are likely to be minimal, we are currently unsure what the record of C. c.f. comtaeformica var. spinata during MIS 3 represents while given the nature of dissolution at this site, we are unable to make a positive identification on the taxa at this time.

\subsection{Early MIS 3, diatom zone 7, (c.59-54 kyr BP)}

Low \%TOC throughout MIS 3 together with very low diatom concentrations at Continent Ridge from the onset of MIS 3 until c.54 kyr BP, indicates very limited palaeoproductivity and the presence of cold, near glacial, palaeoenvironmental conditions throughout the analysed section. Higher \%TOC is observed at the Buguldeika Saddle, South Basin, (Prokopenko et al. 2001a, b) during MIS 3 although values remain below $1 \%$ except during "Kuzmin" catchment erosional events when \%TOC is not indicative of lake palaeoproductivity due to the influx of catchment material. The first appearance of significant diatom assemblages at the Academician Ridge, North Basin, during MIS 3 (Khursevich, et al. 2001a) is approximately synchronous to those at Continent Ridge. In contrast to these two records however, diatom concentrations from the Buguldeika Saddle reveal numerous oscillations throughout the early sections of MIS 3 (Prokopenko et al. 2001a, b) dominated by planktonic taxa (Edlund and Stoermer, 2000). Such differences between Continent Ridge and the Buguldeika Saddle record may indicate a distinct north-south (cold-warm) latitudinal climatic gradient between the sites.

\subsection{Early MIS 3, diatom zone 6-5, Continent Ridge warm interval (c.54-51.5 kyr BP)}

The twelve-fold increase in diatom concentrations, with notable increases for A. baicalensis, in diatom zone 6, c.54-53.3 kyr BP, from levels below $0.091 \times 10^{7}$ valves/g dry wt. to $1.157 \times 10^{7}$ valves $/ \mathrm{g}$ dry wt. suggests a rise in palaeoproductivity and warmer palaeoclimatic conditions in the North Basin of Lake Baikal. The 
subsequent marked increase in diatom concentrations in diatom zone 5, 53.3-51.5 kyr BP, is more pronounced with concentrations reaching $3.026 \times 10^{7}$ valves/g dry wt. though total diatom concentration are below the c. $3 \times 10^{8}$ valves/g dry wt. found at Continent Ridge during MIS 5e (Rioual et al. this volume). Large concentration increases for all diatoms in zone 5, in particular the spring blooming A. baicalensis and autumnal blooming C. minuta, suggest a climate similar to modern day conditions (BDP-Members, 1997) though concentrations of these two species remain significantly below those present in Holocene fossil assemblages (e.g. Edlund and Stoermer, 2000). As already indicated, both these taxa are endemic and found growing in the lake today. A. baicalensis blooms under the ice in spring, between April and May, and can be characterised as a species that is warm-water intolerant. Concentrations of this taxa however, are closely related to the length of ice cover on the lake and to snow thickness on the ice (e.g. Granin et al. 2000). For example, Kelley (1997) estimates that between $4 \%$ and $11 \%$ of solar radiation is able to penetrate through clear ice on Lake Baikal, providing enough energy for algal growth in spring while as little as $5 \mathrm{~cm}$ of snow cover on the ice can reduce solar transmission by a factor of 50 . Thus, when depths of surface snow exceed c.10 cm, reduced light penetration becomes limiting for Lake Baikal diatom growth (Granin et al. 1999; 2000). C. minuta on the other hand blooms early in the autumnal cooling period (after summer stratification) when water transparency (determined by Secchi disc) is at a minimum due to high concentrations of picoplankton leading to increased organic matter in the surface waters of the lake (Kozhova \& Izmest'eva, 1998). Diatoms in zone 5 at Continent Ridge are dominated by very large concentrations of the now extinct C. sp. c.f. gracilis, c.1.0-1.7 x $10^{7}$ valves/g dry wt. The ecology of C. sp. c.f. gracilis is consequently unknown. However, using the ordination analysis we may begin to make some inferences about its possible ecological preferences. For example, it is has a high negative correlation with A. baicalensis along PCA axis 1 , and is positively correlated to A. ambigua, which blooms in lakes during the summer/autumn overturn (Bradbury et al. 2002). This suggests that C. sp. $c f$. gracilis probably bloomed in the autumn overturn period when prevailing climatic conditions were warmer. High diatom concentrations in zones 6 and 5 between 54 kyr BP and $51.5 \mathrm{kyr}$ BP, dominated by C. sp. c.f. gracilis, are therefore synonymous with the presence of warmer interstade conditions at Continent Ridge.

Assuming age models for both the Buguldeika Saddle, which includes a correlation "tie-point" at c.50.3 kyr BP, (Colman et al. 1996; 1999), and Continent Ridge are sufficiently accurate, high diatom concentrations at Continent Ridge between $54 \mathrm{kyr}$ BP and $51.5 \mathrm{kyr}$ BP correlate to similar fluxes in the sedimentary record at the Buguldeika Saddle (Fig. 7) which are dominated by high concentrations of planktonic diatoms including A. baicalensis and C. minuta, each c.20 x $10^{6}$ valves/g dry wt. (Edlund and Stoermer, 2000; Prokopenko et al. 2001a, b). This perspective, suggesting that the warm interstade conditions inferred at Continent Ridge prevailed across Lake Baikal, is reinforced by results from the Academician Ridge, North Basin, (Khursevich, et al. 2001a) which display a short period of high diatom concentrations during early MIS 3. Similar to Continent Ridge, high concentrations of A. baicalensis are found at the Academician Ridge across 
this period but no evidence exists for large fluxes of C. minuta or C. gracilis (Khursevich, et al. 2001a) despite C. minuta being a taxa relatively resilient to dissolution (Battarbee et al. this volume).

\subsection{Kuzmin/Heinrich event 5, diatom zone 4 (51.5-50.2 kyr BP)}

$\mathrm{C} / \mathrm{N}$ ratios, which are largely controlled by the type of organic matter, provide clear evidence that terrestrial input of organic matter at Continent Ridge was limited throughout MIS 3 (Fig. 3). This contrasts with the three 'Kuzmin' catchment erosional events observed at the Buguldeika Saddle that have been attributed to changes in the precipitation regime over the Mongolian and Buryatya steppes to the South of Lake Baikal during North Atlantic Heinrich events (Prokopenko et al. 2001a,b). The use of $\mathrm{C} / \mathrm{N}$ ratios as an indicator of terrigenous or lacustrine supply of organic matter can be problematic when \% TOC is less than 0.3 due to the possibility of inorganic nitrogen within the clay (Meyers and Lallier-Vergès, 1999; Meyers and Teranes, 2001). This threshold is only reached between $26.8 \mathrm{kyr}$ BP and $25.4 \mathrm{kyr}$ BP but is not concurrent with changes in $\mathrm{C} / \mathrm{N}$ ratios suggesting that contributions of inorganic nitrogen in influencing the $\mathrm{C} / \mathrm{N}$ record are unimportant at Continent Ridge. The lack of Kuzmin catchment erosional events at Continent Ridge can therefore be related to its situation away from major catchment inflows whereas the sedimentary record at the Buguldeika Saddle is heavily influenced by the Selenga River which drains over half of the Lake Baikal catchment (Fig. 1).

High diatom concentrations in the Buguldeika Saddle prior to c.50 kyr BP are marked at their culmination, which includes a c. $60 \times 10^{6}$ valves/g dry wt. decrease in diatom concentrations (Edlund and Stoermer, 2000), by Kuzmin/Heinrich event 5 at c.50 kyr BP which established a change in the precipitation regime over the Mongolian and Buryatya steppes (Prokopenko et al. 2001a,b). Based on the Buguldeika Saddle alone it remains unclear whether this decrease in diatom concentration is related to lower productivity, due to a climate cooling associated with the Heinrich event, or to dilution of the sedimentary record via the inwash of catchment material into the Selenga Delta during a Kuzmin event. An abrupt drop in concentrations for all diatom species at Continent Ridge at the approximately the same point, c.51.5 kyr BP, suggests the fall in diatom concentrations at both sites to be correlated through the occurrence of the Heinrich event 5 (Fig. 7). With no evidence for inwash of catchment material at Continent Ridge, evidence here suggests that Heinrich events in the North Atlantic not only caused a change in the precipitation regime over Lake Baikal (Prokopenko et al. 2001a, b) but also initiated large scale cooling in the Central Asian region which resulted in abrupt decreases in aquatic productivity throughout Lake Baikal. While previously established by earlier work on the Chinese loess plateau (e.g. Porter and An, 1995), our results reinforce the suggestions of Prokopenko et al. (2001a, b), that such teleconnections with the North Atlantic extended into Siberia and the northern interior of Central Asia.

Further support for climatic cooling in the region during Heinrich events exists with evidence for glacial advance in the Lake Baikal region over the same period (Back et al. 2000b). Similar large decreases in 
diatom concentrations are also observed at the Academician Ridge approximately half way through the MIS 3 sediment record (Khursevich, et al. 2001a). A MIS 3 chronological framework has yet to be established for the Academician Ridge core BDP-96-2 but, based on the evidence of large synchronous decreases in diatom concentrations at the Continent Ridge and Buguldeika Saddle during Heinrich/Kuzmin event 5 (Fig. 7) the timing of the decline at the Academician Ridge and Continent Ridge are likely to be comparable, particularly given the proximity of the two sites (Fig. 1). The decrease in diatom concentrations at Continent Ridge conflicts though with values of $\delta^{13} \mathrm{C}_{\text {(organic) }}$ which, together with \% TOC values, indicates no notable change in aquatic palaeoproductivity until $43.2 \mathrm{kyr}$ BP. This perhaps suggests that although diatom concentrations decrease at Continent Ridge, caused by climatic cooling associated with Heinrich event 5, blooms of other primary producers, e.g. picoplankton during summer months after ice break-up, were still able to occur.

\subsection{Post-Heinrich event 5 climatic changes, diatom zones 3-1 (c.50.2-39.1 kyr BP)}

The minor increase in diatom concentrations at Continent Ridge in diatom zone three, 50.2-47 kyr BP, particularly for F. heidenii, S. construens var. construens and Staurosirella pinnata (Ehrenb.) Williams \& Round which are able to tolerate and adapt to adverse conditions (Lotter and Bigler, 2000), and the increase in A. baicalensis concentrations to levels similar to those during the c.54-51.5 kyr BP interstade, indicates a return to milder spring conditions in the North basin of Lake Baikal after Heinrich/Kuzmin event 5. A similar recovery is not present in C. sp. c.f. gracilis and C. minuta indicating the occurrence of sub-optimal conditions for these autumnal species to grow. Overall diatom concentrations through this period remain below $0.6 \times 10^{7}$ valves/g dry wt. This record is similar to the diatom record at the Academician Ridge (Khursevich et al. 2001a) but again differs from the more southerly Buguldeika Saddle where concentrations frequently reach pre-Heinrich/Kuzmin event 5 levels (Prokopenko et al. 2001a,b) (Fig. 7) reiterating the possibility of a north-south climatic gradient across Lake Baikal.

The twofold decline in \%TOC at Continent Ridge from 43.2 kyr BP until $39.1 \mathrm{kyr}$ BP together with decreases in A. baicalensis, C. minuta and other diatom concentrations suggests the onset of cooler, near-glacial conditions and lower productivity (Fig. 7). This is reinforced by evidence for glacial re-advance along the northern and eastern Baikal rift by c.40 kyr BP (Back et al. 2000a, b) but conflicts with high values of $\delta^{13} \mathrm{C}_{\text {(organic) }}$ at Continent Ridge which suggests increased aquatic palaeoproductivity (Fig. 3). $\mathrm{C} / \mathrm{N}$ ratios suggest no change in the source of organic matter origin at Continent Ridge (Fig. 3) while diagenesis is unlikely to be a factor in determining $\delta^{13} \mathrm{C}_{\text {(organic) }}$ due its rarity in oligotrophic waters such as Lake Baikal (Prokopenko et al. 1999). If lower productivity at Continent Ridge from $43.2 \mathrm{kyr}$ BP, as inferred from diatom concentrations and \%TOC, was associated with climatic cooling, increased annual ice cover duration may have lowered levels of dissolved $\mathrm{CO}_{2}$ in the water forcing remaining phytoplankton to use isotopically heavier dissolved $\mathrm{HCO}_{3}{ }^{-}$with a $\delta^{13} \mathrm{C}$ value of $\mathrm{c} .1 \%$ (Meyers and Lallier-Vergès, 1999). This would tend to obfuscate the productivity signal in $\delta^{13} \mathrm{C}_{\text {(organic) }}$ resulting in relatively high values of $\delta^{13} \mathrm{C}_{\text {(organic) }}$ at Continent Ridge despite the presence of lower aquatic productivity in the basin. 


\subsection{Late MIS 3 warming (c.39.1-34.7 kyr BP)}

Increases in \% TOC from 0.3 to 0.7 between $39.1 \mathrm{kyr}$ BP and $36.9 \mathrm{kyr}$ BP suggest an increase in productivity and warmer conditions though values remain below Holocene levels of 1.5-2.5 (Prokopenko et al. 2001a, b). During the same period $\delta^{13} \mathrm{C}_{\text {(organic) }}$ decreases by c.2\%o prior to $38.3 \mathrm{kyr}$ BP before increasing by c. $1.5 \%$ to mirror trends observed in \%TOC. We suggest that the warming trend associated with increases in \%TOC and diatom concentrations between $39.1 \mathrm{kyr} \mathrm{BP}$ and $36.9 \mathrm{kyr} \mathrm{BP}$ (Fig 7) caused the $\delta^{13} \mathrm{C}_{\text {(organic) }}$ to revert back to a record of aquatic palaeoproductivity following $\delta^{13} \mathrm{C}_{\text {(organic) }}$ reflectance of shifts in the inorganic carbon pool between $43.2 \mathrm{kyr} \mathrm{BP}$ and $39 \mathrm{kyr} \mathrm{BP}$. Values of \%TOC and $\delta^{13} \mathrm{C}_{\text {(organic) }}$ remain high, relative to values from 43.2 kyr BP to $39 \mathrm{kyr}$ BP, until c.34.7 kyr BP while diatom concentrations show similar patterns, albeit with concentrations significantly below those present between the 54-51.5 kyr BP interstade, suggesting a climatic warming relative to the conditions prevalent between $43.2 \mathrm{kyr}$ BP and $39.1 \mathrm{kyr}$ BP. The three proxies here therefore suggest the presence of a late MIS 3, cool, interstade between $39.1 \mathrm{kyr}$ BP and $34.7 \mathrm{kyr}$ BP. The lack of full interstade conditions here is best represented by the restriction of spring and autumnal diatom blooms, as indicated by low A. baicalensis and C. sp. c.f. gracilis and C. baicalensis concentrations respectively. Consequently, extensive blooms of other summer primary producers, including picoplankton, must have existed to maintain the high \% TOC values after c.39 kyr BP.

Again assuming the Buguldeika Saddle (Colman et al. 1996; 1999) and Continent Ridge chronologies to be reliable, mild conditions of intermediate productivity at Continent Ridge between $39.1 \mathrm{kyr}$ BP and $34.7 \mathrm{kyr}$ BP correlate to a period of prolonged very high, near Holocene, diatom concentrations at the Buguldeika Saddle (Prokopenko et al. 2001a,b) (Fig. 7) of c. $100 \times 10^{6}$ valves/g dry wt. that are dominated by C. gracilis concentrations of $60 \times 10^{6}$ valves/g dry wt. (Edlund and Stoermer, 2000). Initial results from core BDP-99 at

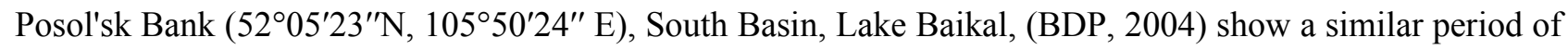
high concentrations during MIS 3. While detailed diatom analysis results and a chronology for the MIS 3 sections are yet to be published at Posol'sk Bank, the high concentrations in this core would be expected to correlate to the same late MIS 3 interval at Continent Ridge and the Buguldeika Saddle.

The presence at this time of high aquatic productivity at the Buguldeika Saddle (Edlund and Stoermer, 2000; Prokopenko et al. 2001a,b) contrasts with the very low diatom concentrations at Continent Ridge of c.0.7 x $10^{6}$ valves/g dry wt. Glacial re-advances in and around the Northern Baikal rift during the second half of MIS 3 may have been sufficiently established in the North Basin as to prevent any increase in spring/autumn diatom productivity during this period through extended seasonal ice/snow cover on the lake. This view is confirmed by low diatom concentrations in the late MIS 3 sections of the core analysed at the Academician Ridge (Khursevich, et al. 2001a). Given the magnitude and intensity of this interstade at the Buguldeika Saddle, dated between $39.1 \mathrm{kyr}$ BP and $34.7 \mathrm{kyr}$ BP at Continent Ridge, with near interglacial diatom concentrations (Edlund and Stoermer, 2000; Prokopenko et al. 2001a, b), this period is likely to correlate to 
the single MIS 3 climatic optima observed elsewhere in Siberia during MIS 3 (e.g. Chlachula, 1999; Nemchinov et al. 1999) indicating the presence of warm conditions across the Lake Baikal/Central Asian region.

The end of the late MIS 3 warm period at the Buguldeika Saddle, again marked by abrupt decreases in diatom concentrations, is linked to Kuzmin/Heinrich event 4 at c.35 kyr BP (Prokopenko et al. 2001a, b). Based on the chronological correlation between the two sites (Fig. 7), Kuzmin/Heinrich event 4 is manifested in the Continent Ridge record by decreases in \%TOC and $\delta^{13} \mathrm{C}_{\text {(organic) }}$ confirming evidence from Heinrich event 5 (section 4.4) and from the Chinese loess plateau (e.g. Porter and An, 1995) for a significant climatic cooling across Central Asia, concomitant with large ice rafting surges in the North Atlantic. As with other studies in Lake Baikal (e.g. Edlund and Stoermer, 2000; Khursevich, et al. 2001a), only low concentrations of diatoms are recorded in the sediments at Continent Ridge towards the end of MIS 3 following Kuzmin/Heinrich event 4 . These low concentrations, together with very low \%TOC and $\delta^{13} \mathrm{C}_{\text {(organic) }}$ (Fig. 3), reflect the onset of cooler conditions throughout the region that heralded the onset of full glacial conditions in MIS 2.

\subsection{Continent Ridge MIS 3/MIS 2 transition}

At the MIS $3 / 2$ transition and into MIS $2, \delta^{13} \mathrm{C}_{\text {(organic) }}$ increases by $4.4 \%$ at Continent Ridge with $\mathrm{C} / \mathrm{N}$ ratios again suggesting no significant change in organic matter source (Fig. 3). A similar, c.2-3\%, increase in $\delta^{13} \mathrm{C}_{\text {(organic) }}$ also occurs at the Academician Ridge (Prokopenko and Williams, 2004) during the same interval. With the onset of full glacial conditions in MIS 2, the increase in $\delta^{13} \mathrm{C}_{\text {(organic) }}$ at both sites is unlikely to reflect increased productivity, as confirmed by very low \% TOC and diatom concentrations at both sites. Diagenesis of sediments is not believed to be a problem in Lake Baikal. Consequently, as between $43.2 \mathrm{kyr}$ BP and 39 kyr BP (section 4.5), we suggest that the increase in $\delta^{13} \mathrm{C}_{\text {(organic) }}$ at Continent Ridge may represent a shift to phytoplankton utilizing the isotopically higher dissolved $\mathrm{HCO}_{3}{ }^{-}$pool due to a lowering of dissolved $\mathrm{CO}_{2}$ levels in the water (section 4.5).

In addition, the $\delta^{13} \mathrm{C}_{\text {(organic) }}$ increase may reflect known changes in $p \mathrm{CO}_{2}$, i.e. the c.20 ppmv fall in $\mathrm{CO}_{2}$ measured at the MIS 3/2 transition in the Byrd and Vostok, Antarctica, ice cores (Neftel et al. 1988; Petit et al.. 1999). Similar evidence for $p \mathrm{CO}_{2}$ changes in Lake Baikal have been found during the Last Glacial-Interglacial Transition (LGIT) at the Buguldeika Saddle with a 3.5-4\%o lowering of $\delta^{13} \mathrm{C}_{\text {(organic) }}$ (Prokopenko et al. 1999) coinciding with a c.60 ppmv increase in $\mathrm{CO}_{2}$, as recorded in the GISP2 Greenland ice core (Smith et al. 1997). Increased annual ice cover during MIS 2 would however be expected to limit lacustrine-atmosphere $\mathrm{CO}_{2}$ exchanges, while the $4.4 \%$ increase accompanying the c.20 ppmv change in $\mathrm{CO}_{2}$ is not consistent with the magnitude of change seen at the Buguldeika Saddle during the LGIT (Prokopenko et al. 1999). Given the complex nature and multiple factors which affect the composition of $\delta^{13} \mathrm{C}_{\text {(organic), }}$, 
caution is required in accepting or rejecting any interpretation. Here we suggest that changes over the MIS 3/MIS 2 boundary are probably a function of both carbon pools.

\subsection{Evidence for climate teleconnections processes between Europe and Central Asia during MIS 3}

Livingstone (1999) and Todd \& Mackay (2003) have demonstrated strong modern climatic linkages between Europe and Central Asia through the North Atlantic and Arctic Oscillations, expressed through Lake Baikal ice characteristics which in turn influence diatom species composition and other biological processes in the lake. Climatic interpretations of the biological record at Continent Ridge, together with results from the Buguldeika Saddle (Prokopenko et al. 2001a, b), suggest climatic teleconnections between Europe and Central Asia also existed through MIS 3 with clear evidence for climatic cooling in the Lake Baikal region during the inception of Heinrich events in the North Atlantic. Widespread evidence for this is further documented through studies on the Chinese Loess Plateau (e.g. Porter and An, 1995; Fang et al. 1999). Determining low-frequency climatic correlation between the two regions however requires caution due to the inherent and unavoidable errors present within all age-depth models, particularly during MIS 3 which lies at the limit of ${ }^{14} \mathrm{C}$ dating.

Relatively few medium to high resolution terrestrial European sequences exist for MIS 3 (Voelker et al. 2002). Despite this, low frequency climatic correlations between Europe and Lake Baikal are apparent for the interstade recorded at Continent Ridge between c.54 kyr BP and c.51.5 kyr BP with widespread warm conditions documented across Europe between c.53.8-50 kyr BP (e.g. Allen et al. 2000; Müller et al. 2003). Evidence also exist for a European warming phase from c.40 kyr BP to $34.9 \mathrm{kyr}$ BP (Allen et al. 2000; Müller et al. 2003) which, on the basis of the respective age models for cores from Lake Baikal, correlates to the relatively warm phase detected at the Buguldeika Saddle and Continent Ridge between $39.1 \mathrm{kyr}$ BP and 34.7 kyr BP. Further, low amplitude, European warming is also apparent from c. 44 kyr BP or c.42.3 kyr BP (Allen et al. 2000; Müller et al. 2003) when biological evidence from Continent Ridge indicates a period of very low productivity and cooler climatic conditions. Further investigation is therefore required to determine whether these teleconnections between Central Asia and Europe were prevalent throughout the MIS 3 period or just during higher-amplitude climatic events.

\section{Conclusions}

Sediments from Continent Ridge, Lake Baikal, indicate the presence of very low to medium diatom concentration of 0.008-3.026 x $10^{7}$ valves/g dry wt. throughout MIS 3 and into MIS 2. While C/N ratios provide no evidence for a 'Kuzmin' event during the interstadial, chronological evidence here indicates that the two warm phases at Continent Ridge, c.54-c.51.5 kyr BP and c.39.1-c.34.7 kyr BP, were terminated by Heinrich events 5 and 4 respectively. This indicates that the onset of Heinrich events in the North Atlantic caused not only changes in the precipitation regime in the central interior of Central Asia (Prokopenko et al. 2001a, b) but also significant climatic cooling and concomitant decreases in aquatic productivity. The 
presence of low to moderate levels of productivity throughout MIS 3, as inferred by $\% \mathrm{TOC}$ and $\delta^{13} \mathrm{C}_{\text {(organic), }}$ until c.43.2 kyr BP suggests though that levels of summer productivity may not have been affected by these climatic changes induced by Heinrich events 5 and 4 . While the c.54-c.51.5 kyr interstade is well represented at Continent Ridge, the c.39.1-c.34.7 kyr BP interstade is not despite evidence from the Buguldeika Saddle (Edlund and Stoermer, 2000; Prokopenko et al. 2001a, b) that this period was significantly warmer. With a lack of a late MIS 3 diatom increases at the Academician (Khursevich, et al. 2001a) and Continent Ridge, we suggest that cooler conditions from c.43.2-c.39 kyr BP and glacial re-advance in the region by c.40 kyr BP (Back et al. 2000a,b) led to the establishment of prolonged ice/snow cover over the North Basin which prevented notable seasonal diatom blooms in the North Basin during the late MIS 3 interstade.

Tentative correlation here of results from Lake Baikal to sequences from Europe, section 4.8 above, suggests climatic teleconnections between the two regions may have prevailed through MIS 3. The accuracy of these correlations though is highly dependent on the reliability of the respective age models at each site. While Heinrich/Kuzmin events 6 to 2 are recorded at the Buguldeika Saddle (Prokopenko et al. 2001a, b), further work is needed to determine whether the close linkages between the North Atlantic region and Central Asia continued through more gradual, low-frequency and low-amplitude, environmental and climatic changes in the full glacial conditions of MIS 4 and MIS 2.

\section{Acknowledgements}

This paper is submitted as part of the CONTINENT research project (www.continent.gfz-potsdam.de/) supported by the European Commission under the Fifth Framework Programme (Contract no. EVK2-2000-00057). The authors would like to thank Carol Arrowsmith for $\% \mathrm{TOC}, \mathrm{C} / \mathrm{N}$ and $\delta^{13} \mathrm{C}$ analysis at NIGL, Hedi Oberhaensli for help with magnetic susceptibility measurements and constructing the age model for the Kasten core at GFZ and Patrick Rioual for providing the MIS 5e C. sp. c.f. gracilis pictures in figure 5. GEAS would like to thank David Morley, Patrick Rioual and Galina Khursevich for advice on Lake Baikal diatom identification. Much of this work was carried out during a NERC MSc studentship award to GEAS (NER/S/M/2002/11028). We would also like to thank Polly Collier for constructive comments on the manuscript and two anonymous reviewers for their helpful comments and suggestions. This is a Royal Society UK-BICER publication.

\section{References}

Allen, J.R.M., Brandt, U., Brauer, A., Hubberten, H.-W., Huntley, B., Keller, J., Kraml, M., Mackensen, A., Mingram, J., Negendank, J.F.W., Nowaczyk, N.R., Oberhaensli, H., Watts, W.A., Wulf, S., Zolitschka, B., 1999. Rapid environmental changes in southern Europe during the last glacial period. Nature. 400, $740-743$. 
Allen, J.R.M., Watts, W.A., Huntley, B., 2000. Weichselian palynostratigraphy, palaeovegetation and palaeoenvironment; the record from Lago Grande di Monticchio, southern Italy. Quaternary International. 73/74, 91-110.

Arnold, N.S., van Andel, T.H., Valen, V., 2002. Extent and Dynamics of the Scandinavian Ice Sheet during Oxygen Isotope Stage 3 (65,000-25,000 yr BP). Quaternary Research. 57, 38-48.

Back, S., De Batist, M., Strecker, M.R., Vanhauwaert, P., 2000a. Quaternary depositional systems in Northern Lake Baikal, Siberia. Journal of Geology. 107, 1-12.

Back, S., Strecker, M.R., De Batist, M., 2000b. Glacial sediment supply control on lacustrine delta and fan architecture in northern Lake Baikal, Siberia. Terra Nostra. 9, 131-139.

Battarbee, R.W. (1986) Diatom analysis. In: Berglund, B.E. (Ed.), Handbook of Holocene Palaeoecology and Palaeohydrology. John Wiley \& Sons Ltd, Chichester, pp. 527-570.

Battarbee, R.W., Kneen, M.J., 1982. The use of electronically counted microspheres in absolute diatom analysis. Limnology Oceanography. 27, 184-188.

Battarbee, R.W., Cameron, N.G., Golding, P., Brooks, S.J., Switsur, R., Harkness, D., Appleby, P.G., Oldfield, F., Thompson, R., Monteith, D.T., McGovern, A., 2001. Evidence for Holocene climate variability from the sediments of a Scottish remote mountain lake. Journal of Quaternary Science. 16, 339-346.

Battarbee, R.W., Mackay, A.W., Jewson, D., Ryves, D.B., Sturm, M., Granin, N.G. (this volume). Differential dissolution of Lake Baikal diatoms: correction factors and implications for palaeoclimatic reconstruction. Global \& Planetary Change.

BDP-Members., 1997. Preliminary results of the first scientific drilling on Lake Baikal, Buguldeika site, Southeastern Siberia. Quaternary International. 37, 3-17.

BDP-Members., 2004. High resolution sedimentary record in a new BDP-99 core from Posol'sk Bank in Lake Baikal. Russian Geology and Geophysics. 45, 149-174.

Bradbury, J.P., Bezrukova, Ye. V., Chernyaeva, G. P., Colman S. M., Khursevich, G., King, J.W., Likhoshway,Ye.V., 1994. A synthesis of post-glacial diatom records from Lake Baikal. Journal of Paleolimnology. 10, 213-252.

Bradbury, J.P., Cumming, B., Laird, K., 2002. A 1500-year record of climatic and environmental change in Elk Lake, Minnesota III: measures of past primary productivity, Journal of Paleolimnology. 27, 321-340. 
Brenner, M., Whitmore, T.J., Curtis, J.H., Hodell, D.A., Schelske, C.L., 1999. Stable isotope $\left(\delta^{13} \mathrm{C}\right.$ and $\left.\delta^{15} \mathrm{~N}\right)$ signatures of sedimented organic matter as indicators of historic lake trophic state. Journal of Paleolimnology. 22, 205-221.

Broecker, W.S., 1998. Palaeocean circulation during the last deglaciation: a bipolar seesaw? Palaeoceanography. 13, 119-121.

Broecker, W.S., 2003. Does the Trigger for Abrupt Climate Change Reside in the Ocean or in the Atmosphere? Science. 300, 1519-1522.

Cane, M.A., 1998. A role for the Tropical Pacific. Science. 282, 59-61.

Channell, J.E.T., 1999. Geomagnetic paleointensity and directional secular variation at Ocean Drilling Program (ODP) site 984 (Bjorn Drift) since 500 ka: comparisons with ODP site 983 (Gardar drift) Journal of Geophysical Research B: Solid Earth 104, 22,937-22,951.

Charlet, F., Fagel, N., De Batist, M., Hauregard, F., Minnebo, B., Meischner D., \& the SONIC Team (this volume). Study of the sedimentary dynamics on elevated plateaus in Lake Baikal (Russia) based on sediment cores and high-resolution geophysical data

Chlachula, J., 1999. Loess-palaeosol stratigraphy in the Yenisey basin, Southern Siberia. Antropozoikum. $23,55-70$.

Colman, S.M., Peck, J.A., Karabanov, E.B., Carter, S.J., Bradbury, J.P., King, J.W., Williams, D.F., 1995. Continental climate response to orbital forcing from biogenic silica records in Lake Baikal. Nature. 378, 769-771.

Colman, S.M., Jones, G.A., Rubin, M., King, J.W., Peck, J.A., Orem, W.H., 1996. AMS radiocarbon analyses from Lake Baikal, Siberia: challenges of dating sediments from a large, oligotrophic lake. Quaternary Science Reviews. 15, 669-684.

Colman, S.M., Peck, J.A., Hatton, J., Karabanov, E.B., King, J.W., 1999. Biogenic silica records from the BDP-93 site and adjacent areas of the Selenga Delta, Lake Baikal, Siberia. Journal of Paleolimnology. 21, 9-17.

D'Errico, F., Goni, M.F.S., 2003. Neanderthal extinction and the millennial scale climatic variability of OIS 3. Quaternary Science Reviews. 22, 769-788.

Demory, F., Nowaczyk, N.R., Witt, A., Oberhänsli, H., (this volume). High-resolution magnetostratigraphy of late Quaternary sediments from Lake Baikal, Siberia: age models and time lag between marine and intracontinental climatic responses. Global and Planetary Change. 
Edlund, M.B., Stoermer, E.F., 2000. A 200,000-year, high-resolution record of diatom productivity and community makeup from Lake Baikal shows high correspondence to the marine oxygen-isotope record of climate change. Limnology and Oceanography. 45, 948-962.

Elliot, M., Labeyrie, L., Bond, G., Cortijo, E., Turon, J.L., Tisnerat, N., Duplessy, J.C., 1998. Millennial-scale iceberg discharges in the Irminger Basin during the last glacial period: relationship with the Heinrich events and environmental settings. Paleoceanography. 13, 433-446.

Elliot, M., Labeyrie, L., Duplessy, J-C., 2002. Changes in North Atlantic deep-water formation associated with the Dansgaard-Oeschger temperature oscillations (60-10 ka). Quaternary Science Reviews. 21, 1153-1165.

Emiliani, C., 1955. Pleistocene temperatures. Journal of Geology. 63, 538-578.

Fang, X.M., Ono, Y., Fukusawa, H., Pan, B.T., Li, J.J., Guan, D.H., Oi, K., Tsukamoto, S., Torii, T., 1999. Asian summer monsoon instability during the past 60,000 years: magnetic susceptibility and pedogenic evidence from the Chinese western Loess Plateau. Earth and Planetary Science Letters 168, 219-232.

Flower, R. J., Likhoshway, Y.V., 1993. Diatom preservation in Lake Baikal. In: Grachev, M.A. (Ed.), Diatom algae as indicators of the changes of climate and environment: Fifth workshop on diatom algae. Botanical Society Publications, Irkutsk, pp. 77-78.

Foged, N., 1993. Some diatoms from Siberia especially from Lake Baikal. Diatom Research. 8, 231-279.

Frontier, S., 1976. Etude de la decroissance des valeurs propres dans une analyze en composantes principales: comparison avec le modele de baton brise. Journal of Experimental Marine Biology. 25, $67-75$.

Grachev, M.A., Likhoshwai, E.V., Vorobyova, S.S., Khlystov, O.M., Bezrukova, E.V., Veinberg, E.V., Goldberg, E.L., Granina, L.Z., Kornakova, E.G., Lazo, F.I., Levina, O.V., Letunova, P.P., Otinov, P.V., Pirog, V.V., Fedotov, A.P., Iaskevich, S.A., Bobrov, V.A., Sukhorukov, F.V., Rezchikov, V.I., Fedorin, M.A., Zolotarev, K.V., Kravchinsky, V.A., 1997. Signals of the paleoclimates of upper Pleistocene in the sediments of Lake Baikal. Russian Geology and Geophysics. 38, 957-980 (in Russian).

Grachev, M.A., Vorobyova, S.S., Likhoshway, Y.V., Goldberg, E.L., Ziborova, G.A., Levina, O.V., Khlystov, O.M., 1998. A high-resolution diatom record of the palaeoclimates of East Siberia for the last 2.5My from Lake Baikal. Quaternary Science Reviews. 17, 1101-1106.

Granin, N.G., Jewson, D.H., Grachev, M.A., Levin, L.A., Zhdanov, A.A., Averin, A.I., Gnatovsky, R.Yu., Gorbunova, L.A., Tcekhanovsky, V.V., Doroshenko, L.M., Minko. N.P., 1999. Turbulent mixing in the water layer just below the ice and its role in development of diatomic algae in Lake Baikal. Doklady Akademii Nauk. 366, 835-839 (in Russian). 
Granin, N.G., Jewson, D.H., Gnatovsky, R.Yu., Levin, L.A., Zhdanov, A.A., Gorbunova, L.A., Tsekhanovsky, V.V., Doroschenko, L.M., Mogilev, N.Yu., 2000. Turbulent mixing under ice and the growth of diatoms in Lake Baikal. Verh. Internat. Verein. Limnol. 27, 2812-2814.

Hendy, I.L., Kennett, J.P., Roark, E.B., Ingram, B.L., 2002. Apparent synchroneity of sub-millennial scale climate events between Greenland and Santa Barbara Basin, California from 30-10 ka. Quaternary Science Reviews. 21, 1167-1184.

Hodell, D.A., Schelske, C.L., 1998. Production, sedimentation and isotopic composition of organic matter in Lake Ontario. Limnology and Oceanography. 43, 200-214.

Horiuchi, K., Minoura, K., Hoshino, K., Oda, T., Nakamura, T., Kawai, T., 2000. Palaeoenvironmental history of Lake Baikal during the last 23,000 years. Palaeogeography, Palaeoclimatology, Palaeoecology. 157, 95-108.

Huntley, B., Alfano, M.J., Allen, J.R.M., Allen et al. Pollard, D., Tzedakis , P.C., de Beaulieu, J-L., Grüger, E., Watts, B., 2003. European vegetation during Marine Oxygen Isotope Stage-3. Quaternary Research. $59,195-212$.

Hutchinson, D.R., Golmshtok, A.J., Zonenshain, L.P., Moore, T.C., Scholz, C.A., Klitford, K.D., 1992. Depositional and tectonic framework of the rift basins of Lake Baikal from multichannel seismic data. Geology. 21, 589-592.

Juggins, S., 1992. zONE version 1.2. Unpublished computer program, ECRC: University College London.

Karabanov, E.B., Prokopenko, A.A., Williams, D.F., Khursevich, G.K., 2000. A new record of Holocene climate change from the bottom sediments of Lake Baikal. Palaeogeography, Palaeoclimatology, Palaeoecology. 156, 211-224.

Kelley, D.E., 1997. Convection in ice-covered lakes: effects on algal suspension. Journal of Plankton Research. 19, 1859-1880.

Khursevich, G.K., Karabanov, E.B., Prokopenko, A.A., Williams, D.F., Kuzmin, M.I., Fedenya, S.A., Gvozdkov, A.A., 2001a. Insolation regime in Siberia as a major factor controlling diatom production in Lake Baikal during the past 800,000 years. Quaternary International. 80-81, 47-58.

Khursevich, G.K., Karabanov, E.B., Prokopenko, A.A., Williams, D.F., Kuzmin, M.I., Fedenya, S.A., $2001 b$. Biostratigraphic significance of new fossil species of the diatom genera Stephanodiscus and Cyclotella from Upper Cenozoic deposits of Lake Baikal, Siberia. Micropaleontology. 47, 47-71.

Kozhova, O.M., Izmest'eva. L.R., 1998. Lake Baikal: Evolution and biodiversity. Backhuys Publishers. 
Livingstone, D.M., 1999. Ice break-up on southern Lake Baikal and its relationship to local and regional air temperatures in Siberia and to the North Atlantic Oscillation. Limnology and Oceanography. 44, 1486-1497.

Lotter, A.F., Bigler, C., 2000. Do diatoms in the Swiss Alps reflect the length of ice cover? Aquatic Sciences. 62, 125-141.

Mackay, A.W., Flower, R.J., Kuzmina, A.E., Granina, L.Z., Rose, N.L., Appleby, P.G., Boyle, J.F., Battarbee, R.W., 1998. Diatom succession trends in recent sediments from Lake Baikal and their relation to atmospheric pollution and to climate change. Philosophical Transactions of the Royal Society of London. B353, 1011-1055.

Mackay, A.W., Battarbee, R.W., Flower, R.J., Granin, N.G., Jewson, D.H., Ryves, D.B., Sturm, M., 2003. Assessing the potential for developing internal diatom-based transfer functions for Lake Baikal. Limnology and Oceanography. 48, 1183-1192.

Mackay, A.W., Ryves, D.B., Battarbee, R.W., Flower, R.J., Granin, N., Jewson, D., Rioual, P.M.J., Sturm, M. (this volume). 1000 years of climate variability in central Asia: assessing the evidence using Lake Baikal diatom assemblages and the application of a diatom-inferred model of snow thickness. Global \& Planetary Change

Maslin, M.A, Seidov, D., Lowe, J., 2001. Synthesis of the nature and causes of rapid climate transitions during the Quaternary. In: Seidov, D., Haupt, B.J., Maslin, M.A. (Eds.), The Oceans and Rapid Climate Change: Past, Present and Future. AGU Geophysical Monograph. 126, 9-52.

Meyers, P.A., Lallier-Verges, E., 1999. Lacustrine sedimentary organic matter records of Late Quaternary paleoclimates. Journal of Paleolimnology. 21, 345-372.

Meyers, P.A., Teranes, J.L., 2001. Sediment Organic Matter. In: Last, W.M., Smol, J.P. (Eds.), Tracking environmental change using lake sediments: Volume 2. Kluwer Academic, Dordrecht, pp. 239-269.

Müller, U.C., Pross, J., Bibus, E., 2003 Vegetation response to rapid climate change in Central Europe during the past 140,000 yr based on evidence from the Füramoos pollen record. Quaternary Research. $59,235-245$

Neftel, A., Oeschger, H., Staffelbach, T., Stauffer, B., 1988. $\mathrm{CO}_{2}$ record in the Byrd ice core 50000-5000 years BP. Nature. 331, 609-611.

Nemchinov, V.G., Budaev, R.T., Rezanov, I.N., 1999. Pleistocene glaciations of the eastern Sayan Mountains. Antropozoikum. 23, 11-15.

Nikiteeva, T.A., Likhoshway, Y.V., 1994. Cyclotella gracilis sp. nov. from Pleistocene material of Lake Baikal, Russia. Diatom Research. 9, 349-353. 
Peterson, L.C., Haug, G.H., Hughen, K.A., Röhl, U., 2000. Rapid changes in the hydrological cycle of the tropical Atlantic during the last glacial. Science. 290, 1947-1951.

Petit, J.R., Jouzel, J., Raynaud, D., Barkov, N.I., Barnola, J.M., Basile, I., Bender, M., Chappellaz, J., Davis, J., Delaygue, G., Delmotte, M., Kotlyakov, V.M., Legrand, M., Lipenkov, V., Lorius, C., Pépin, L., Ritz, C., Saltzman, E., Stievenard, M., 1999. Climate and Atmospheric History of the Past 420,000 years from the Vostok Ice Core, Antarctica. Nature. 399, 429-436.

Piotrowska, N., Bluszcz, A., Demske, D., Granoszewski, W., Heumann, G., In press. Extraction and AMS radiocarbon dating of pollen from Lake Baikal sediments. Radiocarbon. 46.

Porter, S.C., An, Z.S., 1995. Correlation between climate events in the North Atlantic and China during the last glaciation. Nature. 375, 305-308.

Prokopenko, AA., Williams, D.F., 2004. Deglacial methane emission signals in the carbon isotopic record of Lake Baikal. Earth and Planetary Science Letters. 218, 135-147.

Prokopenko, A.A., Williams, D.F., Karabanov, E.B., Khursevich, G.K., 1999. Response of Lake Baikal ecosystem to climate forcing and $\mathrm{pCO}_{2}$ change over the last glacial/interglacial transition. Earth and Planetary Science Letters. 172, 239-253.

Prokopenko, A.A., Williams, D.F., Karabanov, E.B., Khursevich, G.K., 2001a. Continental response to Heinrich events and Bond cycles in sedimentary record of Lake Baikal, Siberia. Global and Planetary Change. 28, 217-226.

Prokopenko, A.A., Karabanov , E.B., Williams, D.F., Kuzmin, M.I., Khursevich, G.K., Gvozdkov, A.A., 2001b. The detailed record of climatic events during the past 75,000 yrs BP from the Lake Baikal drill core BDP-93-2. Quaternary International. 80-81, 59-68.

Rioual, P.M.J., Mackay, A.W., Demoray, F. \& Oberhaensli, H. (this volume) High-resolution diatom record of the Kazantsevo Interglacial stage in Lake Baikal (Siberia). Global \& Planetary Change.

Ryves, D.B., Jewson, D.H., Sturm, M., Battarbee, R.W., Flower, R.J., Mackay, A.W., Granin, N.G., 2003. Quantitative and qualitative relationships between planktonic diatom communities and diatom assemblages in sedimenting material and surface sediments in Lake Baikal, Siberia. Limnology and Oceanography. 48, 1643-1661.

Shackleton, N.J., Opdyke, N.D., 1973. Oxygen isotope and paleomagnetic stratigraphy of equatorial Pacific core V28-238. Quaternary Research. 3, 39-55.

Smith, H.J., Wahler, M., Mastroianni, D., 1997. The $\mathrm{CO}_{2}$ concentration of air trapped in GISP2 ice from the Last Glacial Maximum-Holocene transition. Geophysical Research Letters. 24, 1-4.

Stocker, T.F., 1998. The seesaw effect. Science. 282, 61-62. 
ter Braak, C.J.F., Šmilauer, P., 2002. CANOCO: software for canonical community ordination (version 4.5). Microcomputer Power, New York.

Thouveny, N., de Beaulieu, J.L., Bonifay, E., Creer, M.K., Guiot, J., Icole, M., Johnsen, S., Jouzel, J., Reille, M., Williams, T., Williamson, D., 1994. Climate variations in Europe over the past $140 \mathrm{kyr}$ deduced from rock magnetism. Nature. 371, 503-506.

Todd, M.C., Mackay, A.W., 2003. Large scale climatic controls on Lake Baikal ice cover. Journal of Climate. 16, 3186-3199.

Velichko, A.A. 1984. Late Quaternary Environments of the Soviet Union. (Eds of English Language edition: H.E. Wright \& C.W. Barnosky). University of Minnesota Press, Minneapolis. 327 pp.

van Andel, T.H., 2002. The Climate and Landscape of the Middle Part of the Weichselian Glaciation in Europe: The Stage 3 Project. Quaternary Research. 57, 2-8.

van Kreveld, S., Sarnthein, M., Erlenkeuser, H., Grootes, P., Jung, S., Nadeau, M.J., Pflaumann, U., Voelker, A., 2000. Potential links between surging ice sheets, circulation change, and the Dansgaard-Oeschger cycles in the Irminger Sea, 60-18 kyr. Palaeoceanography. 15, 425-442.

Voelker, A.H.L., Sarnthein, M., Grootes, P., Erlenkeuser, H., Laj, C., Mazaud, A., Nadeau, M.J., Schleicher, M., 1998. Correlation of marine ${ }^{14} \mathrm{C}$ ages from the Nordic Seas with the GISP2 isotope record: implications for ${ }^{14} \mathrm{C}$ calibration beyond 25 ka BP. Radiocarbon. 40, 517-534.

Voelker, A.H.L \& workshop participants., 2002. Global distribution of centennial-scale records for Marine Isotope Stage (MIS) 3: a database. Quaternary Science Reviews. 21, 1185-1212.

William, D.F., Kuzmin, M.I., Prokopenko, A.A., Karabanov, E.B., Khursevich, G.K., Bezrukova, E.V., 2001. The Lake Baikal drilling project in the context of a global lake drilling initiative. Quaternary International. 80-81, 3-15. 


\section{List of tables and figures}

Table 1: Magnetic susceptibility chronology tie-points for Kasten core CON01-603-5 and ${ }^{14} \mathrm{C}$ dates (Piotrovska et al. in press). Magnetic susceptibility measurements on Kasten core produced by Hedi Oberhansli, GFZ.

Figure 1: Location of Continent Ridge Kasten box core CON01-603-5 (Latitude: 5395'46"N Longitude: $\left.108^{\circ} 91^{\prime} 37^{\prime \prime W}\right)$, Lake Baikal.

Figure 2: Continent Ridge low field magnetic susceptibility $\left(10^{-6}\right)$ correlations between pilot core CON 01-603-02 and Kasten core CON 01-603-05 with the Laschamp geomagnetic excursion (c.42 kyr BP) marked at $250 \mathrm{~cm}$ (A, B). Continent Ridge core CON 01-603-05 age depth model with magnetic susceptibility tie-points and calibrated ${ }^{14} \mathrm{C}$ dates (Piotrovska et al. in press) (C and Table 1). Magnetic susceptibility measurements on Kasten core produced by Hedi Oberhansli, GFZ.

Figure 3: $\delta^{13} \mathrm{C}_{\text {(organic) }}$, $\mathrm{C} / \mathrm{N}$ mass ratios and \%TOC for Continent Ridge core CON01-603-5.

Figure 4: Diatom concentrations for taxa above 5\% relative abundance at Continent Ridge core CON01-603-5, arranged according to position along the first and second axis in the PCA biplot, plotted against sediment depth with DDI, percentage of planktonic taxa, PCA first axis samples scores and $\delta^{13} \mathrm{C}_{\text {(organic). }}$ Zonation divisions calculated using CONISS (see text for details). Diatom concentrations for individual taxa are $\times 10^{5}$ valves/g dry wt.

Figure 5: Typical, highly dissolved, C sp. c.f. gracilis from Continent Ridge core CON01-603-5 during MIS 3 (A, B and C) together with "pristine" C. sp. c.f. gracilis from MIS 5e (D, E). Diameter for A and B are 10 $\mu \mathrm{m}, \mathrm{C}=14 \mu \mathrm{m}, \mathrm{D}=7.2 \mu \mathrm{m}, \mathrm{E}=6.5 \mu \mathrm{m}$. MIS 5e pictures provided by Patrick Rioual, UCL.

Figure 6: PCA axis one and two species biplot for Continent Ridge core CON01-603-5 without data at 44.9 kyr BP, due to low numbers of valves counted.

Figure 7: Correlation of diatom concentrations at the Buguldeika Saddle (Prokopenko et al., 2001a,b) to diatom concentrations ( $10^{7}$ valves/g dry wt.), $\delta^{13} \mathrm{C}_{\text {(organic) }}$ and \%TOC at Continent Ridge core CON01-603-5 during the Early (c.54-c.51.5 kyr BP) and Mid (c.39.1-c.34.7 kyr BP) MIS 3 warm phases in Lake Baikal and during 'Kuzmin'/Heinrich events 5 (c.50 kyr BP) and 4 (c.35 kyr BP). Diatom concentrations at the Buguldeika Saddle (Prokopenko et al., 2001a,b) calculated using the methodology of Grachev et al. (1997). 
Published 2005 in Global and Planetary Change 44: 235-253 (http://dx.doi.org/10.1016/j.gloplacha.2004.09.019)

Table 1:

\begin{tabular}{|c|c|c|c|}
\hline \multicolumn{2}{|c|}{ Calibrated ${ }^{14}$ C dates } & \multicolumn{2}{c|}{ Magnetic susceptibility tie-points } \\
\hline Age BP & Kasten core depth (cm) & Age (kyr) BP & Kasten core depth (cm) \\
\hline $1,165 \pm 105$ & 2 & 9.2 & 86.7 \\
\hline $4,520 \pm 100$ & 20 & 15.9 & 95.9 \\
\hline $5,670 \pm 70$ & 26 & 16.5 & 201.3 \\
\hline $6,095 \pm 105$ & 34 & 25.4 & 248 \\
\hline $7,505 \pm 75$ & 41 & 35.3 & 257.3 \\
\hline $9,550 \pm 80$ & 56 & 43.3 & 294.6 \\
\hline $9,685 \pm 145$ & 62 & 46 & 363.5 \\
\hline $12,025 \pm 375$ & 73 & 52 & 370.3 \\
\hline $13,125 \pm 275$ & 89 & 60.2 & \\
\hline $13,950 \pm 400$ & 51 & & \\
\hline
\end{tabular}


Figure 1
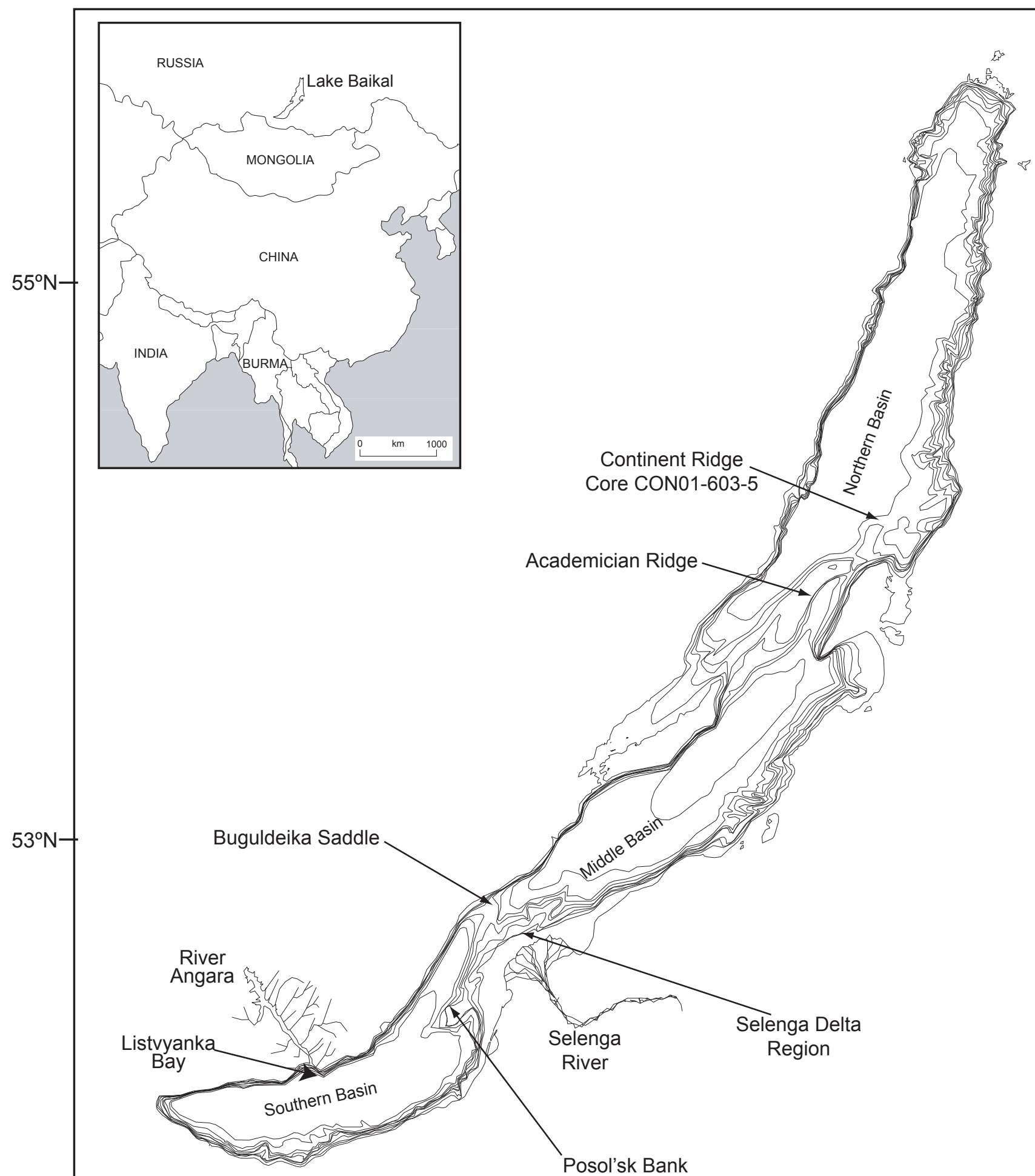

$\begin{array}{llllll}0 \mathrm{~km} & 20 & 40 & 60 & 80 & 100\end{array}$ 
Figure 2

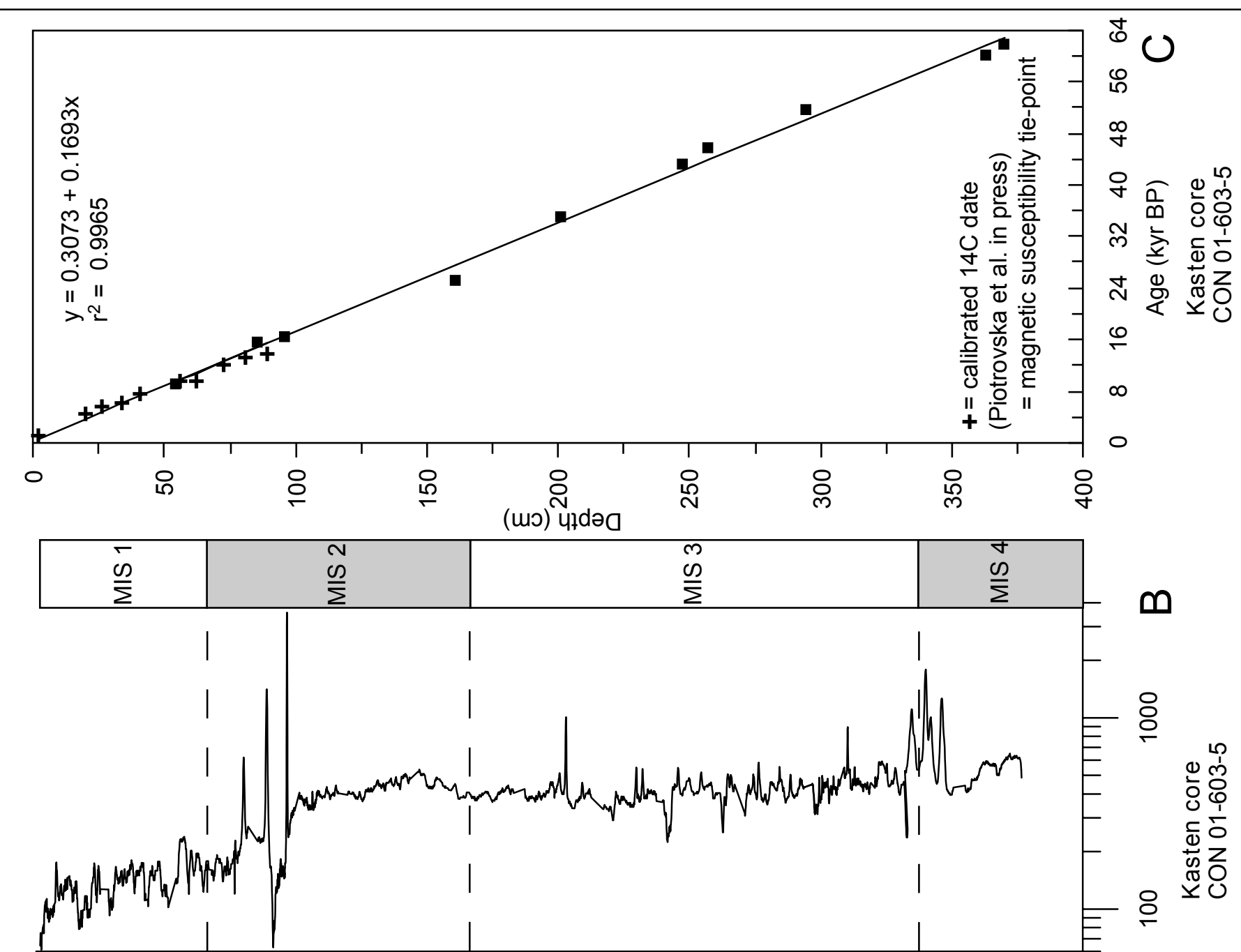

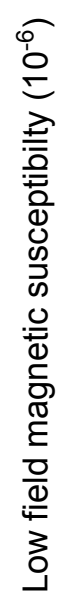
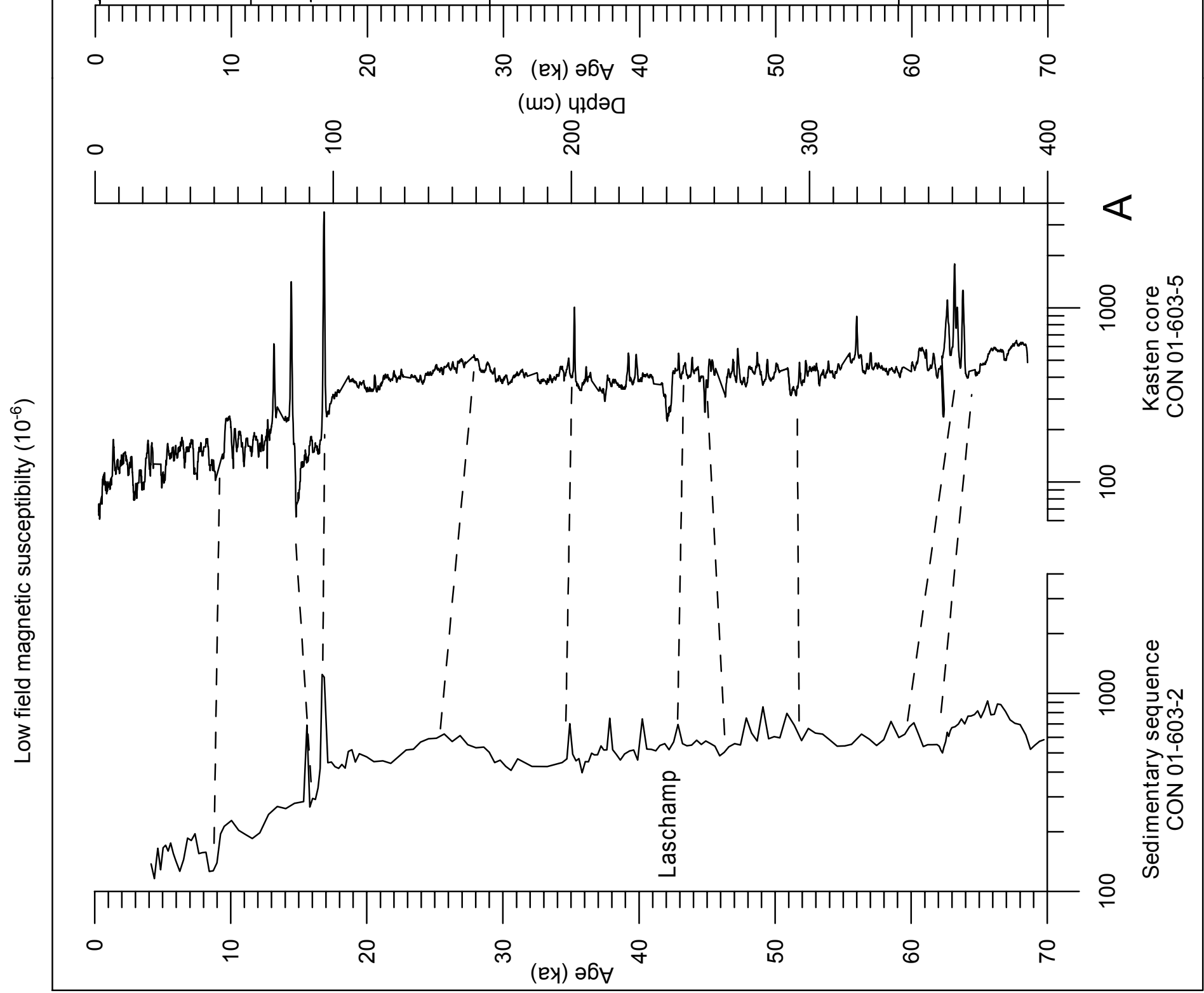
Figure 3

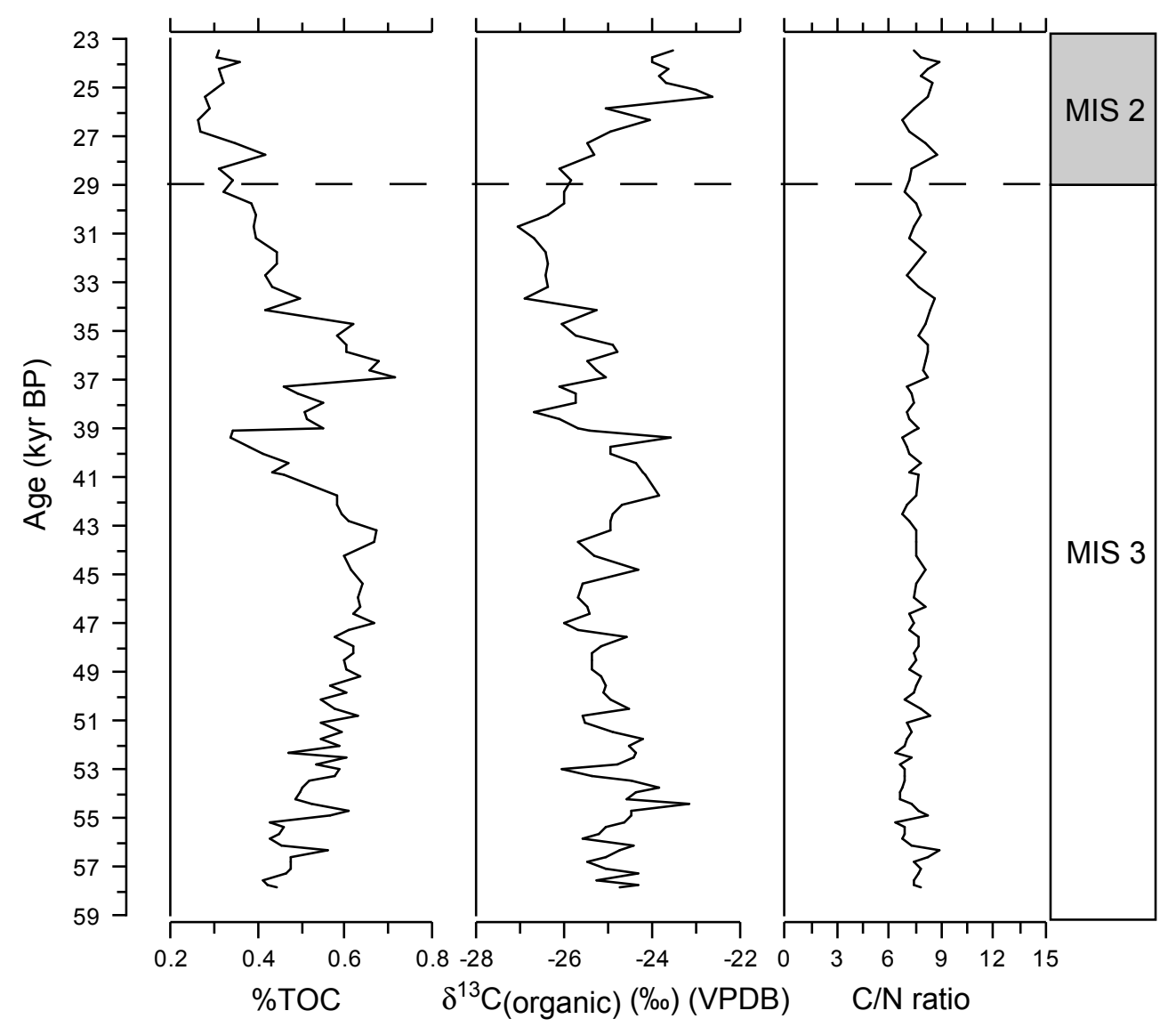


Figure 4
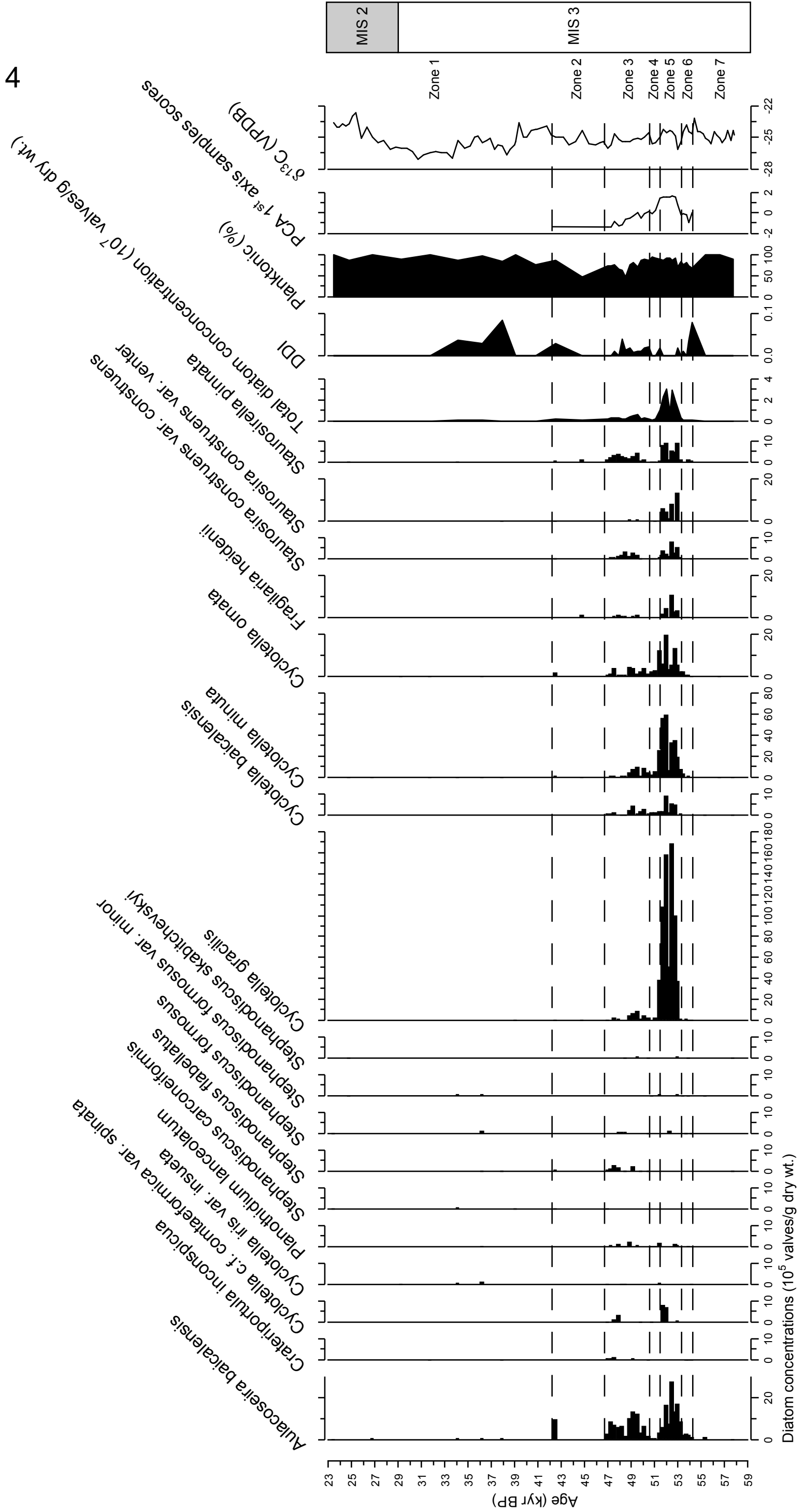
Figure 5

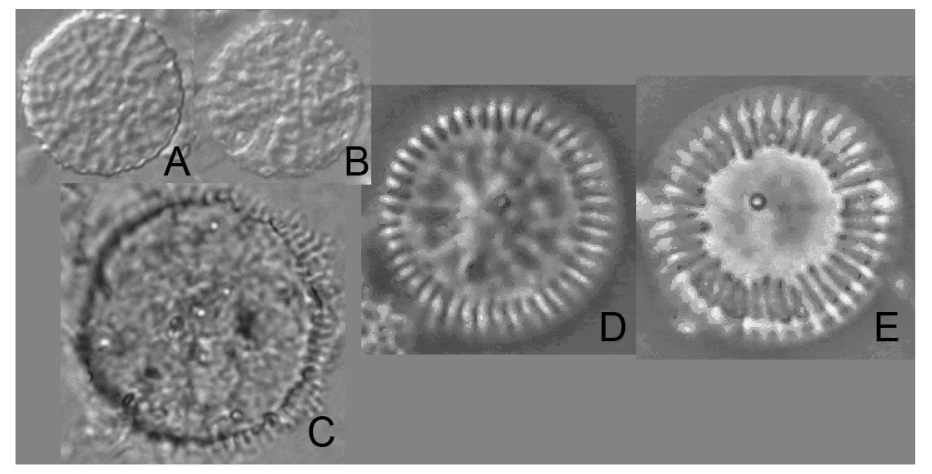


Figure 6

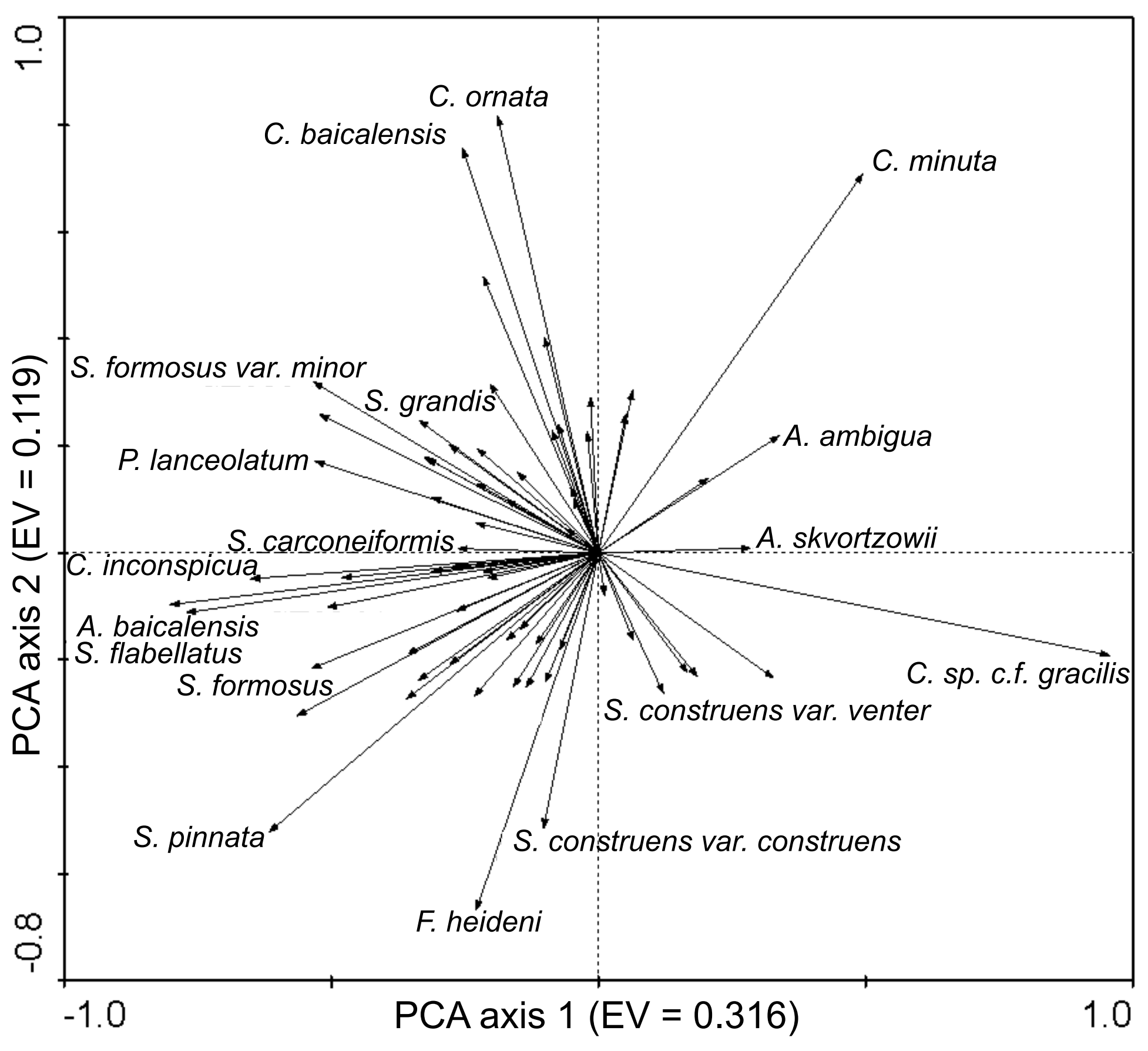


Figure 7

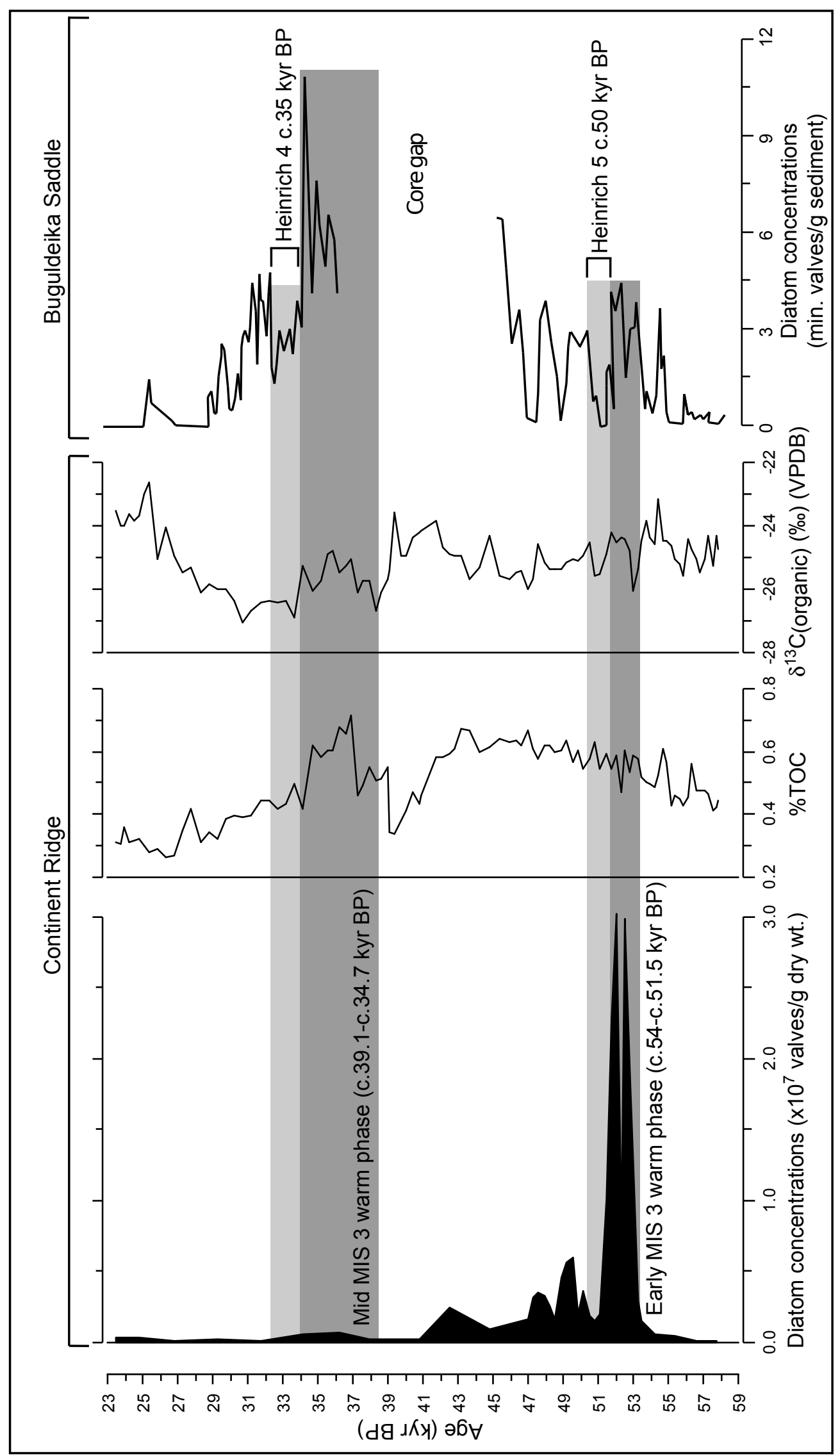

